Article

\title{
Titania and Zinc Oxide Nanoparticles: Coating with Polydopamine and Encapsulation within Lecithin Liposomes-Water Treatment Analysis by Gel Filtration Chromatography with Fluorescence Detection
}

\author{
Xuhao Zhao and Edward P. C. Lai * \\ Ottawa-Carleton Chemistry Institute, Department of Chemistry, Carleton University, \\ Ottawa, ON K1S 5B6, Canada; xuhaozhao@cmail.carleton.ca \\ * Correspondence: edward.lai@carleton.ca; Tel.: +1-613-520-2600 \\ Received: 14 November 2017; Accepted: 2 February 2018; Published: 8 February 2018
}

\begin{abstract}
The interplay of metal oxide nanoparticles, environmental pollution, and health risks is key to all industrial and drinking water treatment processes. In this work we present a study using gel filtration chromatography for the analytical investigation of metal oxide nanoparticles in water, their coating with polydopamine, and their encapsulation within lecithin liposomes. Polydopamine prevents $\mathrm{TiO}_{2}$ and $\mathrm{ZnO}$ nanoparticles from aggregation during chromatographic separation. Lecithin forms liposomes that encapsulate the nanoparticles and carry them through the gel filtration column, producing an increase of peak area for quantitative analysis without any change in retention time to affect qualitative identification. To the best of our knowledge, this is the first report that demonstrates the potential application of lecithin liposomes for cleaning up metal oxide nanoparticles in water treatment. Encapsulation of graphene quantum dots by liposomes would allow for monitoring of nanoparticle-loaded liposomes to ensure their complete removal by membrane ultrafiltration from treated water.
\end{abstract}

Keywords: encapsulation; gel filtration chromatography; fluorescence detection; lecithin; liposomes; nanoparticles; polydopamine; titania; water treatment analysis; zinc oxide

\section{Introduction}

Nanomaterials exhibit novel physicochemical properties that continue to promote their use in various industrial manufacturing processes. The top applications of nanomaterials in North America includes catalysts, coatings, electronics, food products, paints, rubber tires, and textiles [1]. Three metal oxide nanoparticles having sizes between 1 and 100 nanometers, namely titania $\left(\mathrm{TiO}_{2}\right)$, zinc oxide $(\mathrm{ZnO})$, and ceria $\left(\mathrm{CeO}_{2}\right)$, are produced in high tonnage for use as additives in nanomaterials worldwide. $\mathrm{TiO}_{2}$ nanoparticles are used as a fine whitener in cosmetics and sunscreen products because of their brightness, high refractive index, and resistance to discoloration. However, concerns are increasing recently about environmental pollution and the health risks of widespread exposure to $\mathrm{TiO}_{2}$ nanoparticles. Long et al. reported that $\mathrm{TiO}_{2}$ nanoparticles can produce reactive oxygen species that cause many diseases including immortalized brain microglia in mice [2,3]. Trouiller et al. found that $\mathrm{TiO}_{2}$ nanoparticles are inducers of DNA damage and genetic instability in mice [4]. Chang et al. found a high percentage of biological toxicity when the liver and kidneys were exposed to $\mathrm{TiO}_{2}$ nanoparticles [5]. Grande and Tucci lately discussed the potential human health risks induced by exposure to $\mathrm{TiO}_{2}$ nanoparticles [6]. Disdier demonstrated that, despite a lack of brain translocation, exposure to $\mathrm{TiO}_{2}$ nanoparticles induces blood-brain carrier physiology alteration and 
neuro-inflammation that may lead to central nervous system disorders [7]. Shah et al. have emphasized the biological and chemical concerns about $\mathrm{TiO}_{2}$ nanoparticles as well as their toxicological profile at the molecular level [8]. Water pollution has become a major concern for many countries in recent years due to the rapid industrialization of nanotechnologies. Hence, the development of industrial wastewater and drinking water treatment systems to remove $\mathrm{TiO}_{2}$ among other metal oxide nanoparticles is vital to providing long-term environmental and public health security [9-11].

Polydopamine (PDA) is a multifunctional biopolymer structurally similar to naturally occurring melanin [12]. PDA nanocapsules have been successfully used for drug delivery [13]. Their good biocompatibility and biodegradability have facilitated biomedical development for use as both a photoacoustic imaging contrast agent and a chemothermotherapy agent for tumors [14]. The high wrapping tendency of PDA has favored the fabrication of Au-PDA nanoparticles with an ultrathin $(1.3 \mathrm{~nm})$ shell for high sensitivity, uniformity, and stability in shell-isolated nanoparticle-enhanced Raman spectroscopy [15]. A new magnetic molecularly imprinted polymer has been prepared by polymerizing dopamine on the surface of $\mathrm{Fe}_{3} \mathrm{O}_{4}$ nanoparticles in the presence of thionine template [16]. Novel ultrafiltration-adsorption membranes have been designed via decorating the walls of membrane internal pores with PDA nanoparticles for removal of $\mathrm{Pb}^{2+}, \mathrm{Cd}^{2+}$ and $\mathrm{Cu}^{2+}$ [17]. A highly efficient nanofiltration membrane can be fabricated via surface decoration of metal-organic framework/graphene oxide composite onto PDA-coated polysulfone substrate [18]. The PDA coating can be dissolved in an alkaline solution to regenerate the membrane [19]. Dopamine can be added to coat metal oxide nanoparticles under ultrasonication with PDA, which breaks up all coagulated nanoparticles and prevents any re-aggregation to merit accurate analysis [20].

Lecithin, being a mixture of phospholipids, is the main component of lipid matrix in biological membranes [21]. Crude lecithin is commercially available at a low cost in large quantities. This natural zwitterionic surfactant can self-organize into lamellar $\mathrm{L}_{\alpha}$ mesophase when small amounts of water are admixed [22]. Liposomes of soy lecithin are readily prepared by strong sonication [23], dehydration-rehydration-heating [24], and thin film ultrasonic dispersion [25,26] to form an inner aqueous compartment surrounded by a concentric bilayer of phospholipids. They are environmentally friendly and simple to manufacture at a high lipid concentration [27]. Microfluidization is more efficient than ultrasonication in particle size reduction [28]. As the lipid bilayer membrane has an average particle size from $110 \mathrm{~nm}$ to $990 \mathrm{~nm}$ [29], they are a cost-effective option for many applications to deliver drugs, imaging agents, peptides, proteins, and nucleic acids [29-34]. Nano-liposomes of crude soy lecithin are also effective for cleaning fuel oil-contaminated sands and soils [35]. The development of polymer-liposome complexes for biomedical applications is growing rapidly [36,37]. A liposome-Ag-Au core/shell nanocomposite is good for drug delivery by near infrared laser irradiation [38]. All these previous works contributed to our idea that lecithin liposomes can readily encapsulate metal oxide nanoparticles.

Gel filtration chromatography (GFC) is a versatile analytical technique that permits the effective separation of proteins and other biological molecules in an aqueous buffer solution [39]. Separation is achieved using a porous gel matrix to which analyte molecules, for steric reasons, have different degrees of access solely on the basis of molecular size [40]. Water is commonly used to pre-equilibrate the gel-filtration matrix. The mechanism of size exclusion is also applicable for the separation of nanoparticles after surface functionalization to improve their stability [41-44]. Unfortunately, $\mathrm{TiO}_{2}$ nanoparticles form aggregates in aqueous suspension as a function of the electrolyte ionic strength and nature of the divalent cations typically found in surface water and soil [45]. $\mathrm{TiO}_{2}$ nanoparticles selectively adsorb water-soluble organic phosphates [46]. Lecithin at $5 \mu \mathrm{g} / \mathrm{mL}$ can stabilize these nanoparticles [47]. Mesoporous carbon can be nano-emulsified in a lecithin O/W system to be trapped in the pores of $\mathrm{TiO}_{2}$ for cosmetic applications [48].

In this work, GFC was used to investigate $\mathrm{TiO}_{2}$ and $\mathrm{ZnO}$ nanoparticles in water by fluorescence detection, after coating them with PDA and encapsulating them within lecithin liposomes. It was crucial to prevent aggregation of these nanoparticles in every water sample, to carry them through 
the gel filtration column without excessive retention, and to obtain reproducible detection peaks during chromatographic separation. Potential applications for cleaning up metal oxide nanoparticles during industrial wastewater and drinking water treatment are proposed. The idea of using lecithin liposomes for nanoparticle pre-concentration and removal in water treatment analysis is innovative. Its development into an industrial procedure is feasible as the reported critical micellar concentration of lecithin is around $0.4 \mathrm{mg} / \mathrm{mL}$ and the assembled lecithin liposomes have a typical size of 100-1000 nm, which is sufficient to accommodate all sizes of nanoparticles.

\section{Materials and Methods}

\subsection{Materials}

Methanol was purchased from VWR (Mississauga, ON, Canada). Soy lecithin in oil form was obtained from Vita Health Products (Winnipeg, MB, Canada). Titanium dioxide nanopowder (21 nm primary particle size), zinc oxide powder (maximum particle size: $45 \mathrm{~nm}$ ), and Tris base $\left(\mathrm{pK}_{\mathrm{a}}=8.2\right)$ were obtained from Sigma-Aldrich (Oakville, ON, Canada).

\subsection{Coating of $\mathrm{TiO}_{2}$ or $\mathrm{ZnO}$ Nanoparticles with Polydopamine}

$\mathrm{TiO}_{2}$ or $\mathrm{ZnO}$ nanoparticles $(100 \mathrm{mg})$, dopamine $(100 \mathrm{mg})$, Tris $(63 \mathrm{mg})$, and distilled deionized water $(60 \mathrm{~mL})$ were mixed by magnetic stirring for $1 \mathrm{~h}$. The mixture was centrifuged at $4500 \mathrm{rpm}$ for $30 \mathrm{~min}$, the supernatant was discarded, and the $\mathrm{TiO}_{2}$-PDA or ZnO-PDA nanoparticles were re-suspended in deionized water $(40 \mathrm{~mL})$ for all subsequent experiments.

\subsection{Lecithin Liposomes Blank}

A thick syringe needle was inserted to a capsule of lecithin oil for half an hour to suck lecithin slowly into the syringe. A mixture of lecithin $(0.05 \mathrm{~mL})$ and methanol $(4.95 \mathrm{~mL})$ was sonicated by an unbranded ultrasonic homogenizer $(20 \mathrm{kHz}, 108 \mathrm{~W}$, sequentially powered on for $2 \mathrm{~s}$, and powered off for $5 \mathrm{~s}$ ) for $5 \mathrm{~min}$ at room temperature to form a uniform dispersion. This dispersion was mixed with distilled deionized water, obtained from a Millipore Milli-Q water system (Bedford, MA, USA), at a ratio of 1:2 by volume to serve as a lecithin liposomes blank, for comparison with $\mathrm{TiO}_{2}$ or $\mathrm{ZnO}$ nanoparticles encapsulated within lecithin liposomes, in GFC-FD analysis. In a mixture of methanol and water (1:2 ratio), the dispersion of lecithin liposomes is stable for at least an hour, which was enough time the GFC-FD analysis.

\subsection{Lecithin Liposome-Encapsulated $\mathrm{TiO}_{2}$ or $\mathrm{ZnO}$ Nanoparticles}

To prepare lecithin liposome-encapsulated $\mathrm{TiO}_{2}$ or $\mathrm{ZnO}$ nanoparticles, different concentrations of nanoparticles (from 0.01 to $1.0 \mathrm{mg} / \mathrm{mL}$ prepared daily in our laboratory using distilled deionized water as the dispersion medium) were mixed with the lecithin liposomes blank at a ratio of 2:1 by volume. The mixtures were homogenized by the ultrasonic homogenizer $(20 \mathrm{kHz}, 108 \mathrm{~W}$, sequentially powered on for $2 \mathrm{~s}$ and powered off for $5 \mathrm{~s}$ ) for $5 \mathrm{~min}$ at room temperature to form uniform suspensions before GFC-FD analysis. Furthermore, different amounts $(50-250 \mu \mathrm{L})$ of lecithin liposomes were added to either distilled deionized water $(500 \mu \mathrm{L})$ or $1.0 \mathrm{mg} / \mathrm{mL} \mathrm{TiO}_{2}$ nanoparticles $(500 \mu \mathrm{L})$, followed by addition of distilled deionized water until the total volume was $750 \mu \mathrm{L}$.

\subsection{UV-Visible Absorption and Fluorescence Emission Spectroscopy}

Fluorescence excitation and emission spectra of samples were measured on a Horiba Jobin Yvon (Edison, NJ, USA) FluoroMax-4 spectrofluorometer using a slit width of $4 \mathrm{~nm}$ for both emission and excitation. First under excitation by UV light at a wavelength of $300 \mathrm{~nm}$, the emission wavelength was scanned from 350 to $550 \mathrm{~nm}$ to obtain a fluorescence emission spectrum. Next by monitoring the emission intensity at a wavelength of $450 \mathrm{~nm}$, the excitation wavelength was scanned from 200 to $400 \mathrm{~nm}$ to obtain a fluorescence excitation spectrum. 


\subsection{Gel Filtration Chromatography}

Gel filtration chromatography was performed on a Shimadzu LC-6A system (Columbia, MD, USA), initially using a short column (Shodex SHSB-807G, $50 \times 8 \mathrm{~mm}, 35 \mu \mathrm{m}$, MWCO 10,000) for rapid analysis and eventually on a long column (Shodex SB-807HQ, $300 \times 8 \mathrm{~mm}$, MWCO 10,000) for extended analysis. Both columns were purchased from Canadian Life Science (Peterborough, ON, Canada). Distilled deionized water was used as the mobile phase at a flow rate ranging from $0.3 \mathrm{~mL} / \mathrm{min}$ to $1.0 \mathrm{~mL} / \mathrm{min}$. The GFC system was coupled to a Jasco FP-2020 Plus intelligent fluorescence detector (Easton, MA, USA). Fluorescence detection (FD) employed $\lambda_{\mathrm{ex}}=365 \mathrm{~nm}$ and $\lambda_{\mathrm{em}}=460 \mathrm{~nm}$ for $\mathrm{TiO}_{2}$-PDA determination, or $\lambda_{\mathrm{ex}, \max }=350 \mathrm{~nm}$ and $\lambda_{\mathrm{em}, \max }=395 \mathrm{~nm}$ for $\mathrm{TiO}_{2}$ determination.

\section{Results and Discussion}

Before GFC could be used to investigate the coating of $\mathrm{TiO}_{2}$ nanoparticles in water with PDA and their encapsulation within lecithin liposomes, their fluorescence properties were studied in order to determine the excitation and emission wavelengths for selective and sensitive detection. Ultrasonic homogenization was evaluated for facilitating the encapsulation of $\mathrm{TiO}_{2}-\mathrm{PDA}$ nanoparticles by lecithin liposomes, by observing if reproducible peaks could be obtained from GFC-FD analysis for the chromatographic characterization of lecithin liposome-encapsulated $\mathrm{TiO}_{2}-\mathrm{PDA}$ nanoparticles. A short GFC column was initially used for rapid analysis and a long column was used for extended analysis to characterize their retention time, retention volume, and peak area at different flow rates of the mobile phase. After the feasibility of determining $\mathrm{TiO}_{2}$ nanoparticles in the presence of lecithin liposomes was confirmed, the potential application of lecithin liposomes for encapsulating other metal oxide nanoparticles would be demonstrated with $\mathrm{ZnO}$ nanoparticles. Optimization of the new method was carried out by adding different amounts of lecithin liposomes to a fixed concentration of $\mathrm{TiO}_{2}$ nanoparticles. In order to develop a cost effective technology for the removal of metal oxide nanoparticles in water treatment, graphene quantum dots were tested as a fluorescent sensor for monitoring the complete removal of nanoparticle-loaded liposomes from the treated water.

\subsection{Fluorescence Spectroscopy}

The fluorescence property of lecithin liposome-encapsulated $\mathrm{TiO}_{2}$ nanoparticles was determined first. The maximum excitation and emission wavelengths were measured to be $\lambda_{\text {ex,max }}=350 \mathrm{~nm}$ and $\lambda_{\mathrm{em}, \max }=395 \mathrm{~nm}$ in Figure $1 \mathrm{a}, \mathrm{a}^{\prime}$. Next, $\lambda_{\mathrm{ex}}=365 \mathrm{~nm}$ and $\lambda_{\mathrm{em}}=460 \mathrm{~nm}$ were determined for lecithin-bound $\mathrm{TiO}_{2}-\mathrm{PDA}$ nanoparticles in Figure $1 \mathrm{~b}, \mathrm{~b}^{\prime}$. Both excitation spectra look very similar because lecithin liposomes are nearly transparent, the PDA coating is only a couple nanometers thick, and $\mathrm{TiO}_{2}$ nanoparticles were mainly responsible for absorption of the UV light from $230 \mathrm{~nm}$ to $400 \mathrm{~nm}$. The two emission spectra are obviously different due to energy transfer from $\mathrm{TiO}_{2}$ nanoparticles emission at $395 \mathrm{~nm}$ to PDA emission at $460 \mathrm{~nm}$ in Figure $1 \mathrm{~b}$ only. Efficient and facile coating of $\mathrm{TiO}_{2}$ nanoparticles with PDA had previously been reported in the scientific literature $[49,50]$. The transmission electron microscopy images of $\mathrm{TiO}_{2}$ and $\mathrm{TiO}_{2}-\mathrm{PDA}$ nanoparticles in Figure 2 below show how difficult it is to see their difference due to a thin organic PDA coating.

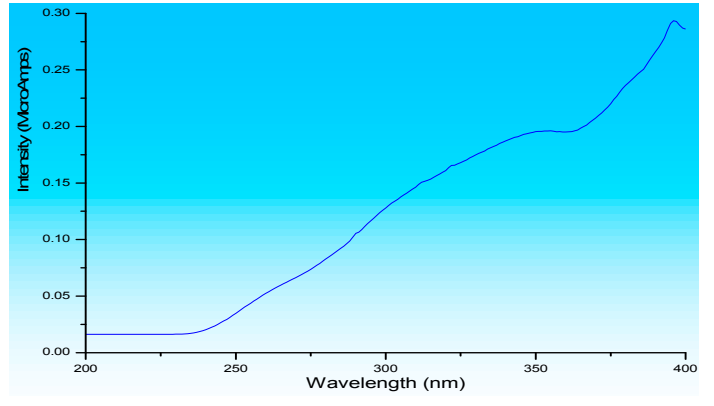

(a)

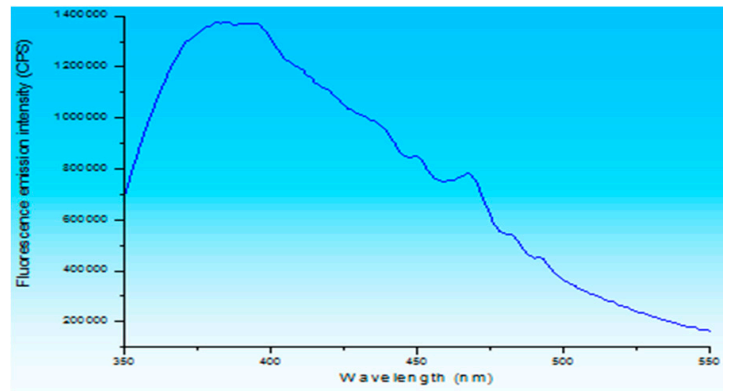

$\left(a^{\prime}\right)$

Figure 1. Cont. 


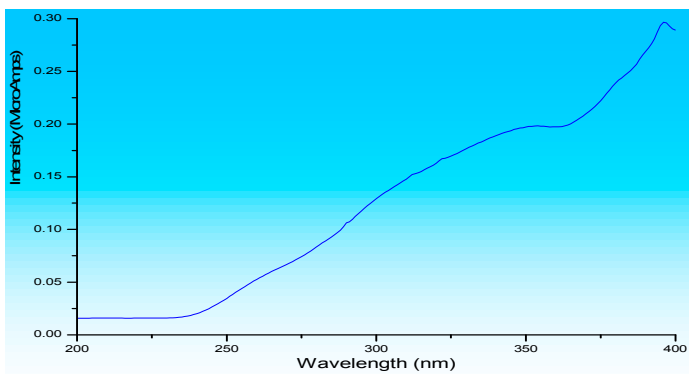

(b)

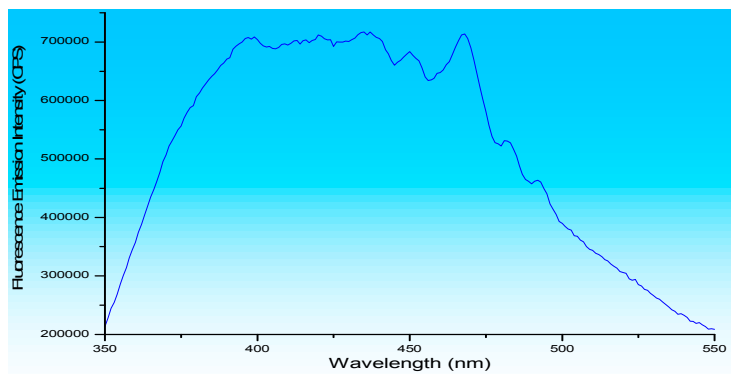

$\left(\mathbf{b}^{\prime}\right)$

Figure 1. Fluorescence excitation spectra using $\lambda_{\mathrm{em}}=450 \mathrm{~nm}$ : (a) lecithin liposome-encapsulated $\mathrm{TiO}_{2}$ nanoparticles; and (b) lecithin liposome-encapsulated $\mathrm{TiO}_{2}-\mathrm{PDA}$ nanoparticles. Fluorescence emission spectra using $\lambda_{\mathrm{ex}}=300 \mathrm{~nm}$ : ( $\mathbf{a}^{\prime}$ ) lecithin liposome-encapsulated $\mathrm{TiO}_{2}$ nanoparticles; and $\left(\mathbf{b}^{\prime}\right)$ lecithin liposome-encapsulated $\mathrm{TiO}_{2}$-PDA nanoparticles.

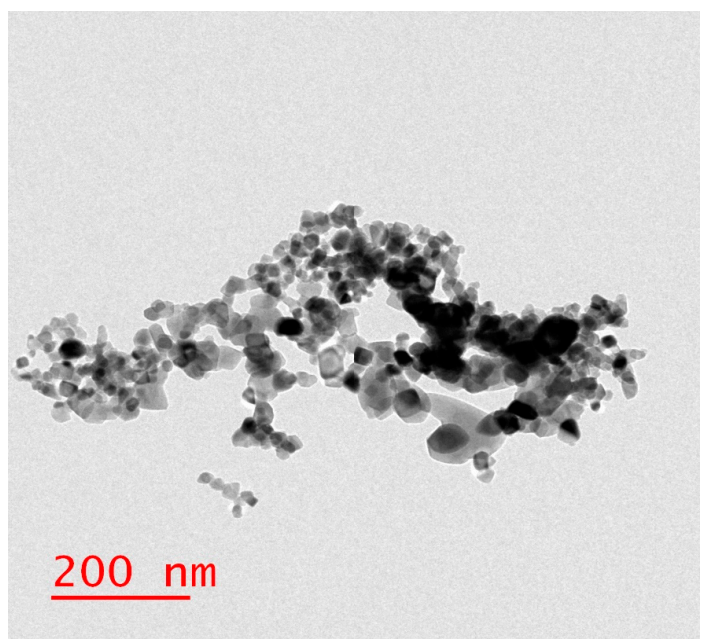

(a)

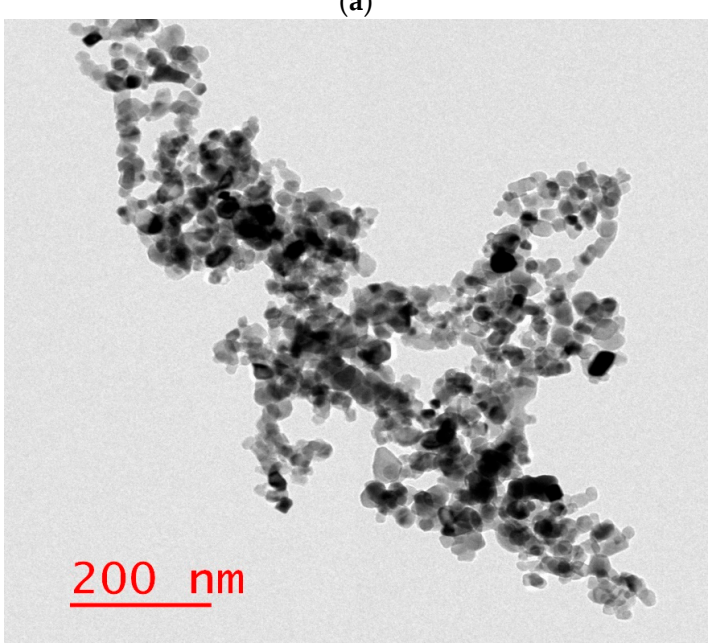

(b)

Figure 2. Transmission electron microscopy images: (a) $\mathrm{TiO}_{2}$ nanoparticles; and (b) $\mathrm{TiO}_{2}-\mathrm{PDA}$ nanoparticles.

\subsection{Rapid GFC-FD Analysis of Lecithin Liposome-Encapsulated $\mathrm{TiO}_{2}-P D A$ Nanoparticles}

A short GFC column $(50 \times 8 \mathrm{~mm})$ was initially used for rapid analysis of lecithin liposomeencapsulated $\mathrm{TiO}_{2}-\mathrm{PDA}$ nanoparticles. As expected, a PDA coating prevented the $\mathrm{TiO}_{2}$ nanoparticles 
from aggregation during chromatographic separation. Ultrasonic homogenization apparently facilitated the encapsulation of $\mathrm{TiO}_{2}$ nanoparticles by lecithin liposomes, thus yielding reproducible peaks for the chromatographic characterization of lecithin liposome-encapsulated $\mathrm{TiO}_{2}-\mathrm{PDA}$ nanoparticles. The standard calibration curve in Figure 3 shows that the GFC-FD peak area increased as the concentration of lecithin liposome-encapsulated $\mathrm{TiO}_{2}-\mathrm{PDA}$ nanoparticles increased. At the lowest concentrations of lecithin liposome-encapsulated $\mathrm{TiO}_{2}-\mathrm{PDA}$ nanoparticles studied, peak areas were very close to each other around the quantification limit of the GFC-FD analysis method. Next, lecithin liposome-encapsulated PDA nanoparticles and PDA nanoparticles were also analyzed by rapid GFC-FD for a comparison. Their peak areas in Figure $4 b, c$ are significantly smaller than that in Figure 4a despite equivalent concentrations. This difference in peak area can certainly be attributed to the presence versus absence of $\mathrm{TiO}_{2}$ nanoparticles. A rapid method for the quantitative analysis of $\mathrm{TiO}_{2}$-PDA nanoparticles by GFC-FD in $6 \mathrm{~min}$ is thus verified for the linear dynamic range from $0.05 \mathrm{mg} / \mathrm{mL}$ to $1.00 \mathrm{mg} / \mathrm{mL}$.

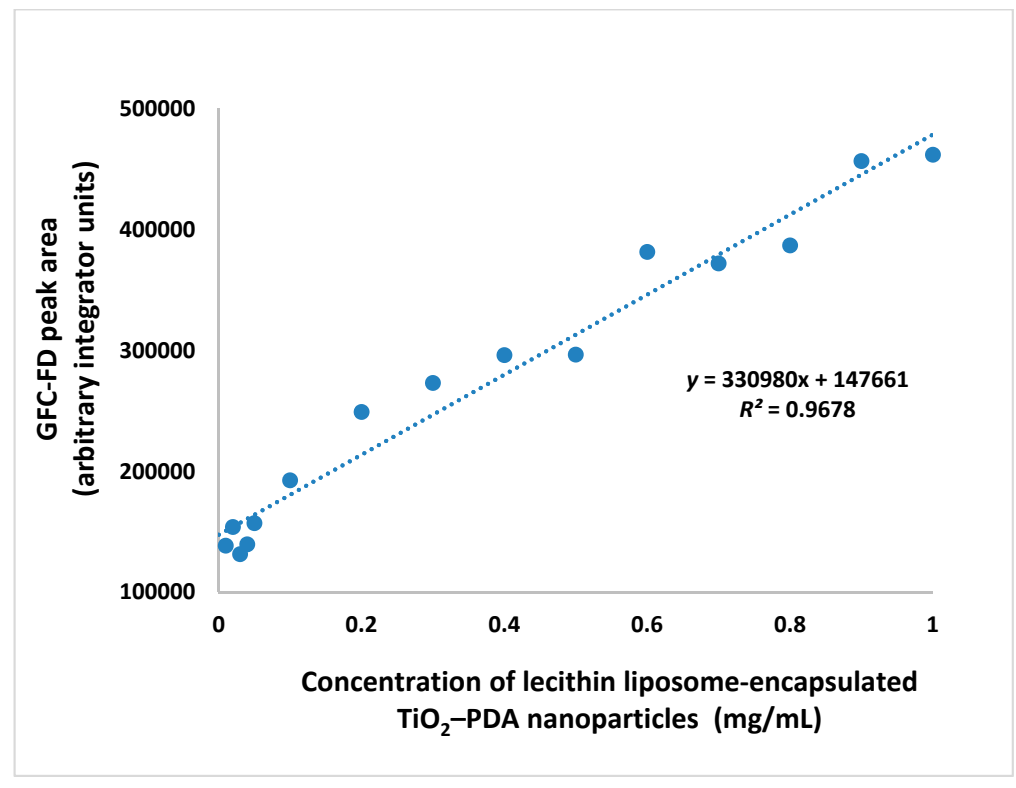

Figure 3. Standard calibration curve for rapid GFC analysis of lecithin liposome-encapsulated $\mathrm{TiO}_{2}$-PDA nanoparticles, using $\lambda_{\mathrm{ex}}=365 \mathrm{~nm}$ and $\lambda_{\mathrm{em}}=460 \mathrm{~nm}$ for FD.

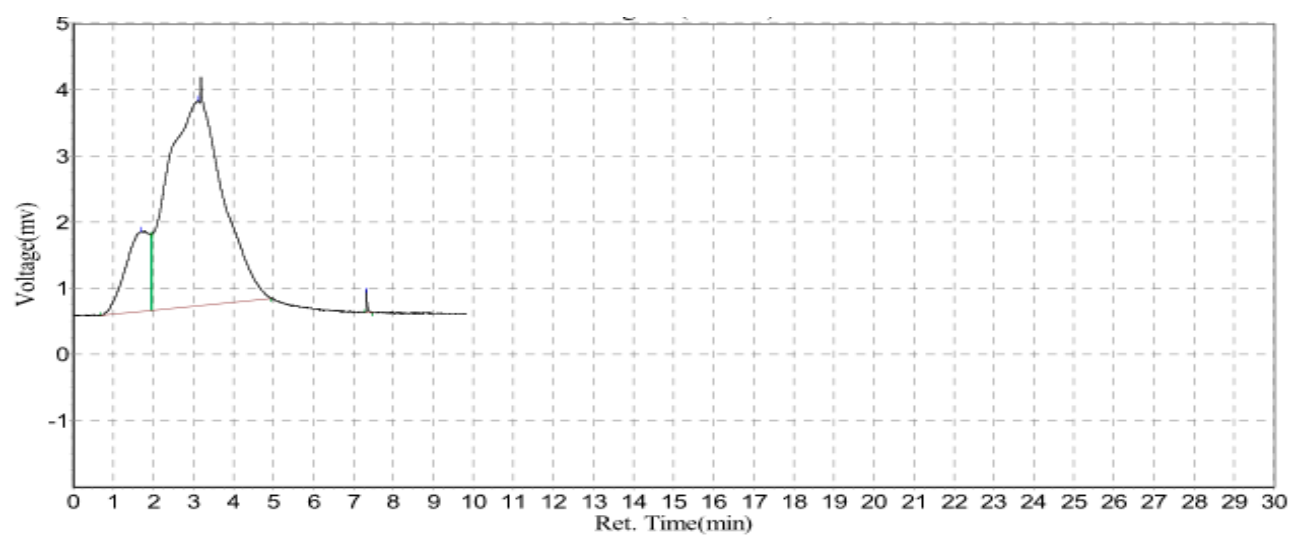

(a)

Figure 4. Cont. 


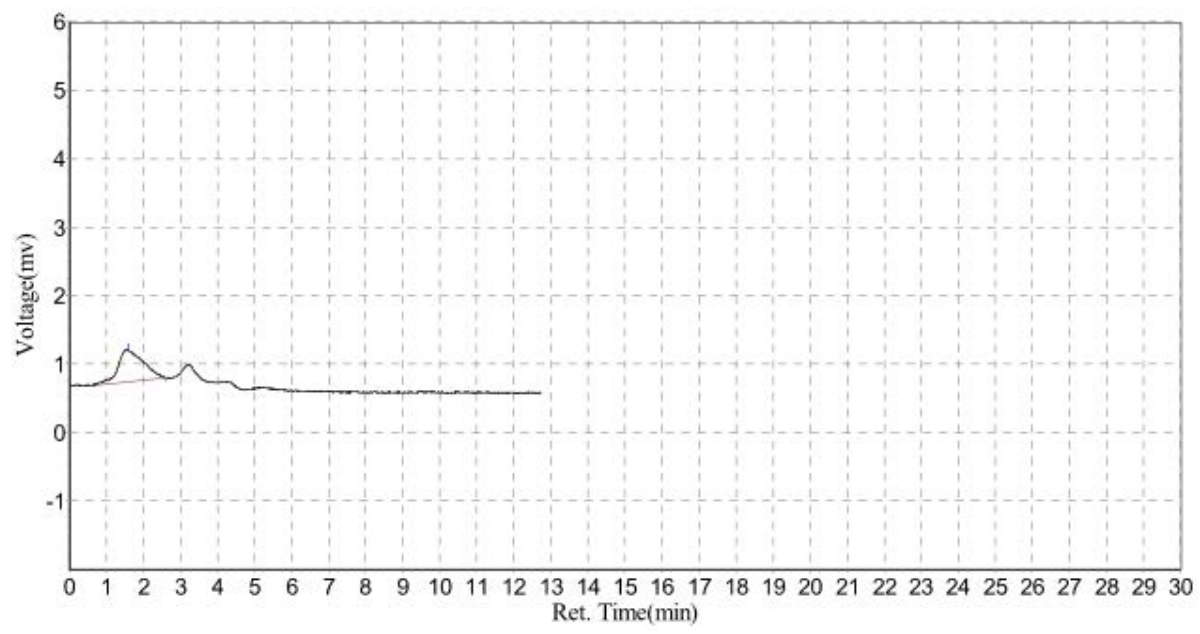

(b)

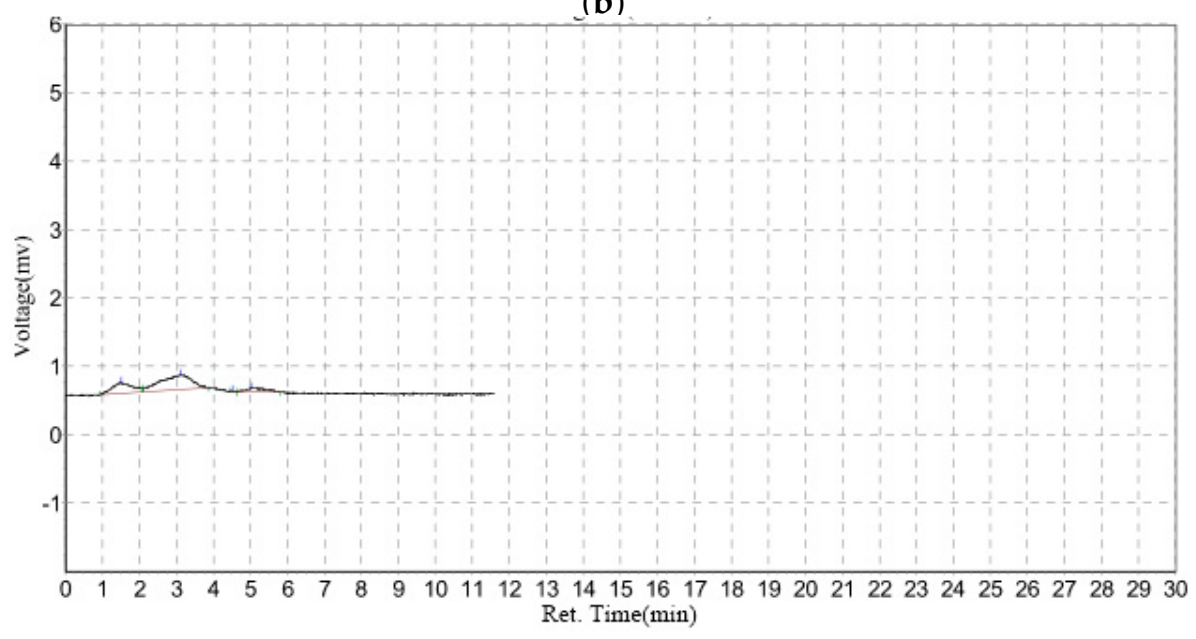

(c)

Figure 4. Rapid GFC analysis: (a) lecithin liposome-encapsulated $\mathrm{TiO}_{2}-\mathrm{PDA}$ nanoparticles $(1 \mathrm{mg} / \mathrm{mL})$; (b) lecithin liposome-encapsulated PDA nanoparticles; and (c) PDA nanoparticles, using $\lambda_{\mathrm{ex}}=365 \mathrm{~nm}$ and $\lambda_{\mathrm{em}}=460 \mathrm{~nm}$ for FD.

\subsection{Rapid GFC-FD Analysis of Lecithin Liposome-Encapsulated $\mathrm{TiO}_{2}$ Nanoparticles}

Lecithin liposome-encapsulated $\mathrm{TiO}_{2}$ nanoparticles (without PDA coating) were analyzed by rapid GFC for elucidating the analytical merits of PDA. The peak area in Figure 5a was larger than that for lecithin liposome-encapsulated $\mathrm{TiO}_{2}$-PDA nanoparticles in Figure $4 \mathrm{a}$ where the fluorescence from $\mathrm{TiO}_{2}$ nanoparticles was quenched by the PDA coating. Using next the maximum excitation and emission wavelengths $\lambda_{\mathrm{ex}, \max }=350 \mathrm{~nm}$ and $\lambda_{\mathrm{em}, \max }=395 \mathrm{~nm}$ for FD, a stronger peak was obtained for lecithin liposome-encapsulated $\mathrm{TiO}_{2}$ nanoparticles in Figure $5 \mathrm{~b}$. A new standard calibration curve was constructed in Figure 6 to validate the linear dynamic range from $0.05 \mathrm{mg} / \mathrm{mL}$ to $1.00 \mathrm{mg} / \mathrm{mL}$. The maximum wavelengths $\left(\lambda_{\mathrm{ex}, \max }=350 \mathrm{~nm}\right.$ and $\lambda_{\mathrm{em}, \max }=395 \mathrm{~nm}$ ) generated a better calibration curve than the initial wavelengths ( $\lambda_{\mathrm{ex}}=365 \mathrm{~nm}$ and $\lambda_{\mathrm{em}}=460 \mathrm{~nm}$ ) in terms of sensitivity and linearity. These results indicate the real possibility of determining lecithin liposome-encapsulated $\mathrm{TiO}_{2}$ nanoparticles down to $0.10 \mathrm{mg} / \mathrm{mL}$. Unfortunately, the blank (a mixture of lecithin liposomes and distilled deionized water in a ratio of 1:2 by volume) produced a peak area as large as those obtained from all standard concentrations below $0.10 \mathrm{mg} / \mathrm{mL}$. This could probably be attributed to stronger fluorescence from the phosphatidylcholine and phosphatidyl-ethanolamine contents of lecithin at these maximum wavelengths [51]. It became important that the blank peak from lecithin liposomes be separated from the lecithin liposome-encapsulated $\mathrm{TiO}_{2}$ peaks by using a longer GFC column for extended analysis. 


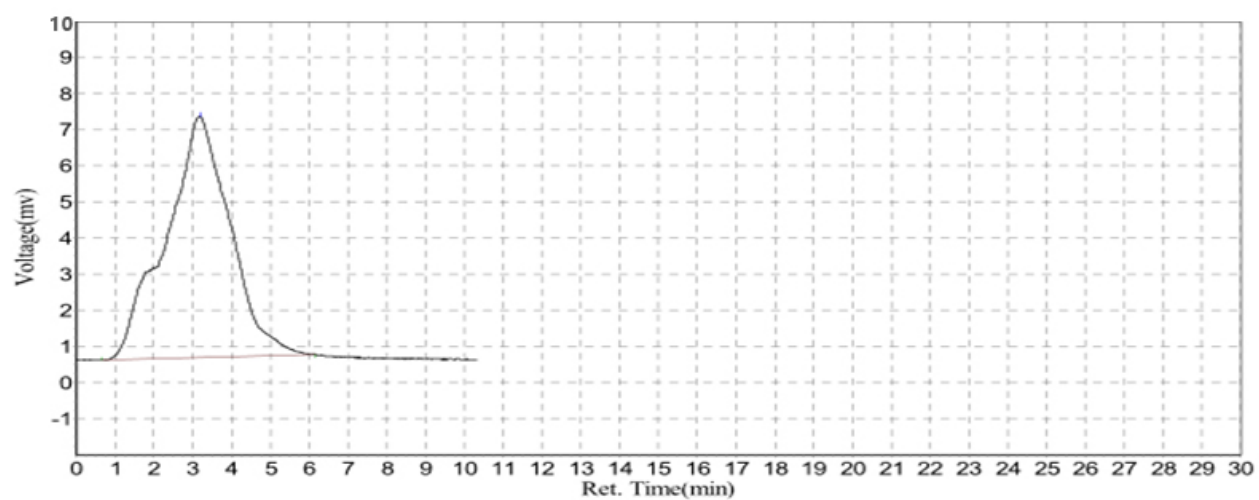

(a)



(b)

Figure 5. Rapid GFC analysis of (a) lecithin liposome-encapsulated $\mathrm{TiO}_{2}$ nanoparticles $(1 \mathrm{mg} / \mathrm{mL})$, using (a) $\lambda_{\mathrm{ex}}=365 \mathrm{~nm}$ and $\lambda_{\mathrm{em}}=460 \mathrm{~nm}$; and (b) $\lambda_{\mathrm{ex}, \max }=350 \mathrm{~nm}$ and $\lambda_{\mathrm{em}, \max }=395 \mathrm{~nm}$, for FD.

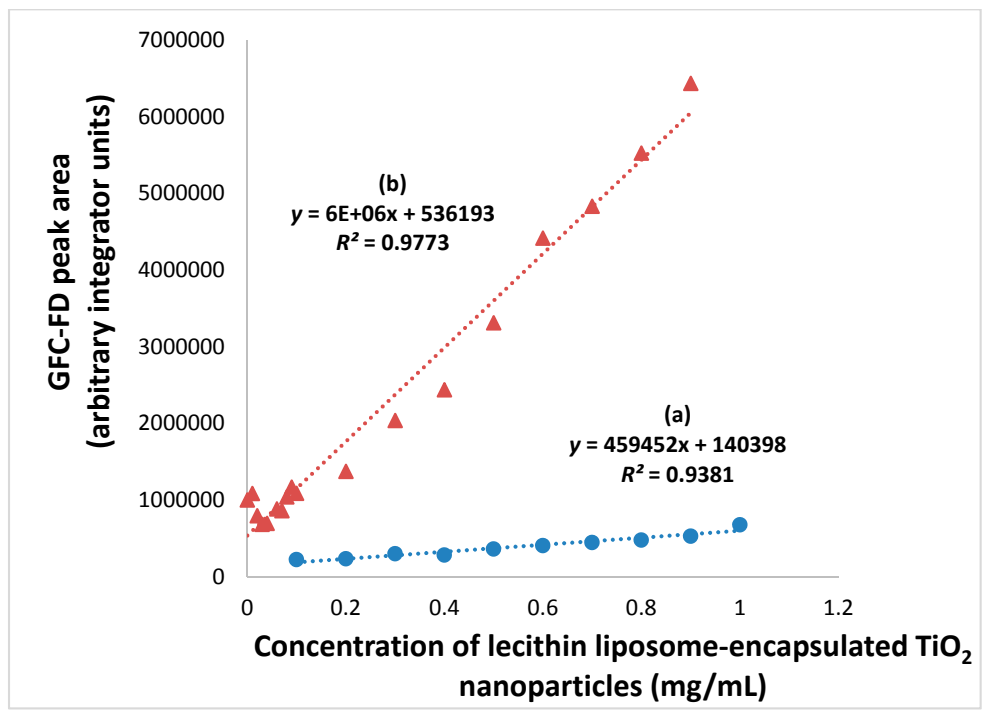

Figure 6. Standard calibration curves for rapid GFC analysis of lecithin liposome-encapsulated $\mathrm{TiO}_{2}$ nanoparticles using (a) $\lambda_{\mathrm{ex}}=365 \mathrm{~nm}$ and $\lambda_{\mathrm{em}}=460 \mathrm{~nm}$; and (b) $\lambda_{\mathrm{ex}, \max }=350 \mathrm{~nm}$ and $\lambda_{\mathrm{em}, \max }=395 \mathrm{~nm}$, for FD. 


\subsection{Extended GFC-FD Analysis of Lecithin Liposome-Encapsulated $\mathrm{TiO}_{2}$ Nanoparticles}

A long GFC column $(300 \times 8 \mathrm{~mm})$ was next used for extended analysis of lecithin liposomeencapsulated $\mathrm{TiO}_{2}$ nanoparticles, $\mathrm{TiO}_{2}$ nanoparticles, and lecithin liposomes separately. It was evidenced from the extended GFC-FD chromatograms (not shown here) that $\mathrm{TiO}_{2}$ nanoparticles (injected at a low concentration of $0.01 \mathrm{mg} / \mathrm{mL}$ ) were retained excessively on the long column as no peak appeared using a mobile phase flow rate increasing from $0.5 \mathrm{~mL} / \mathrm{min}$ up to $1.5 \mathrm{~mL} / \mathrm{min}$. These results can be explained based on the time needed for water to wash the $\mathrm{TiO}_{2}$ nanoparticles through the entire length of gel filtration matrix in the column. Fortunately, encapsulation of $\mathrm{TiO}_{2}$ nanoparticles within lecithin allowed them to go through the column together quickly to appear as one combo peak at a retention time of $4.15 \mathrm{~min}$. It was confirmed that the peak area of lecithin liposome-encapsulated $\mathrm{TiO}_{2}$ nanoparticles was larger than that for lecithin liposomes alone, to our great delight.

The influence of flow rate (from 0.5 to $1.0 \mathrm{~mL} / \mathrm{min}$ ) on the retention time, retention volume, and peak area of lecithin liposome-encapsulated $\mathrm{TiO}_{2}$ nanoparticles (injected at a low concentration of $0.01 \mathrm{mg} / \mathrm{mL}$ ) was systematically investigated. An increase of flow rate obviously decreased their retention time in Figure $7 \mathrm{a}$, while the retention volume stayed constant at $4.03 \pm 0.05 \mathrm{~mL}$ with a nearly horizontal trend line in Figure $7 \mathrm{~b}$, and the peak area decreased in Figure $7 \mathrm{c}$ because the peak became narrower as expected. The unidirectional trends of these results, within experimental errors, confirmed consistently the feasibility of determining $\mathrm{TiO}_{2}$ nanoparticles in the presence of lecithin liposomes.

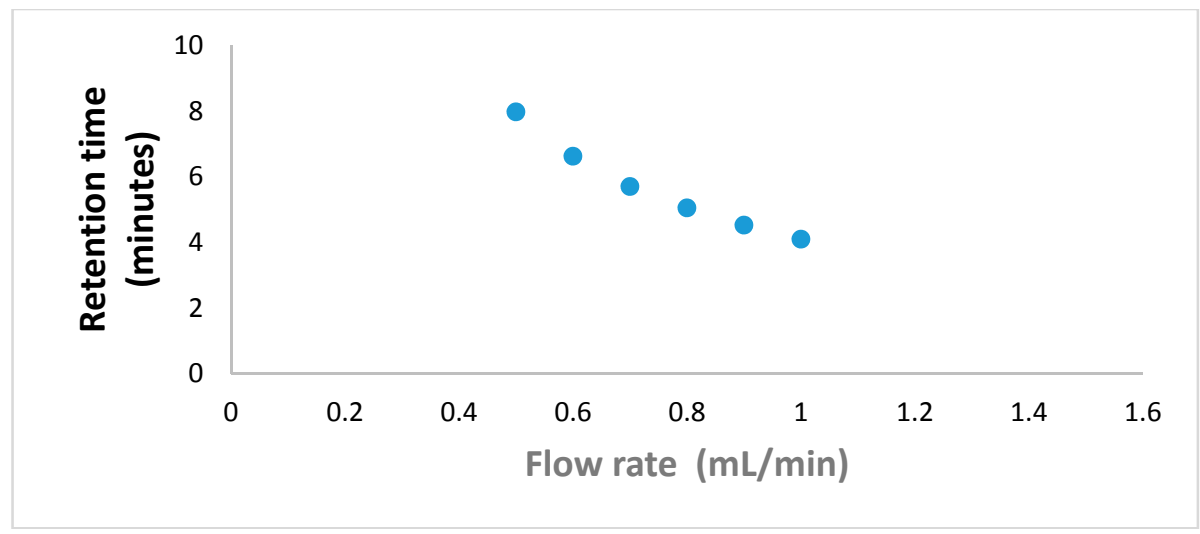

(a)

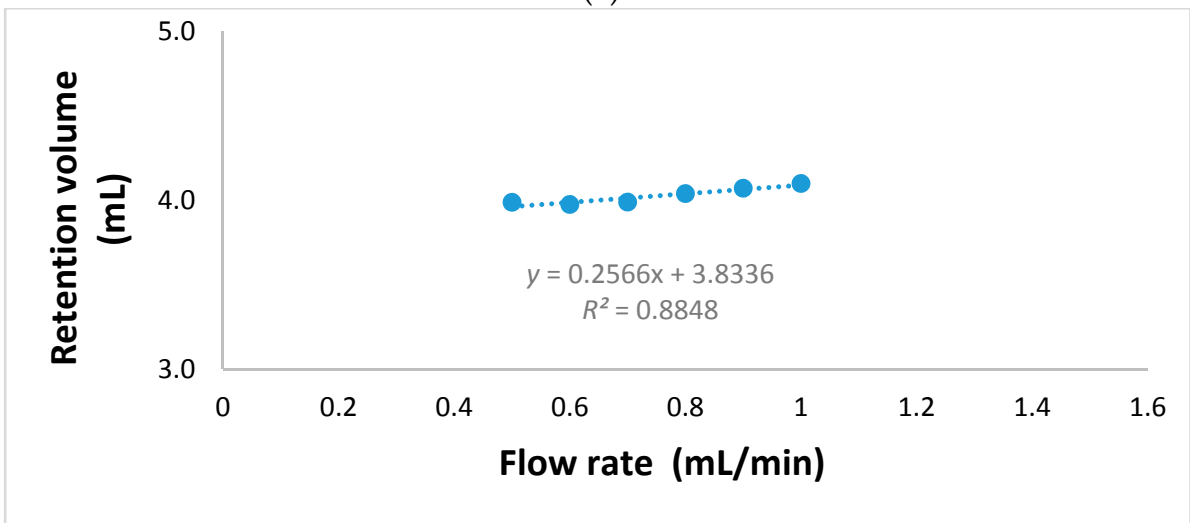

(b)

Figure 7. Cont. 


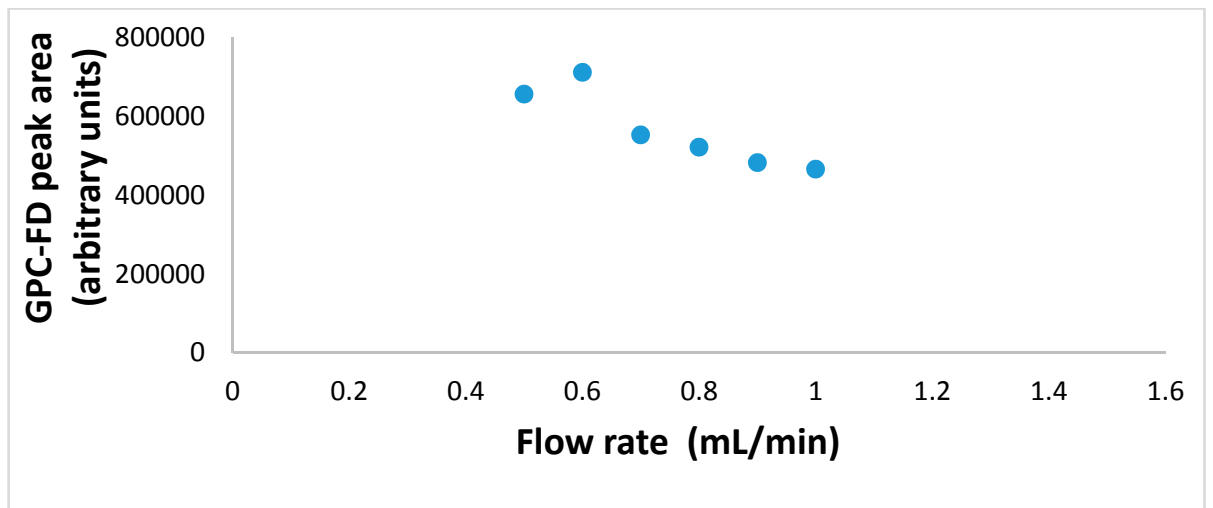

(c)

Figure 7. Effects of flow rate on (a) retention time; (b) retention volume; and (c) peak area of lecithin liposome-encapsulated $\mathrm{TiO}_{2}$ nanoparticles $(0.01 \mathrm{mg} / \mathrm{mL})$ in extend GFC analysis, using $\lambda_{\text {ex,max }}=350 \mathrm{~nm}$ and $\lambda_{\mathrm{em}, \max }=395 \mathrm{~nm}$ for FD.

The influence of flow rate (from 0.3 to $1.5 \mathrm{~mL} / \mathrm{min}$ ) on the retention time, retention volume, and peak area of lecithin liposome-encapsulated $\mathrm{TiO}_{2}$ nanoparticles (injected at a high concentration of $1.0 \mathrm{mg} / \mathrm{mL}$ ) was also systematically investigated. An increase of flow rate again decreased their retention time in Figure 8a while their retention volume remained constant at $3.95 \pm 0.07 \mathrm{~mL}$ with a nearly horizontal trend line in Figure $8 \mathrm{~b}$. Interestingly, the retention volume for lecithin liposomes was actually higher, indicating a smaller size than lecithin liposome-encapsulated $\mathrm{TiO}_{2}$ nanoparticles. This makes sense because the high concentration of encapsulated $\mathrm{TiO}_{2}$ nanoparticles could enlarge the size of each and every lecithin liposome. As smaller molecules have greater access and larger molecules are excluded from the gel filtration matrix, they would be eluted from the GFC column in decreasing order of size. The difference in peak area between lecithin liposomes and lecithin liposome-encapsulated $\mathrm{TiO}_{2}$ nanoparticles allowed easily for quantitative determination of $\mathrm{TiO}_{2}$ nanoparticles at this high concentration. Again, the peak area decreased in Figure 8c because the peak became narrower as the flow rate was increased.


(b)

Figure 8. Cont. 


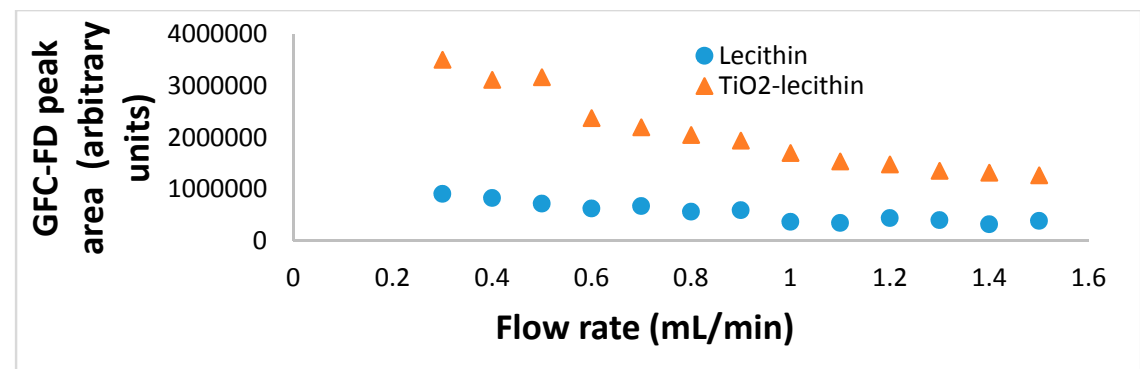

(c)

Figure 8. Effects of flow rate on (a) retention times; (b) retention volumes; and (c) peak areas of lecithin liposomes and lecithin liposome-encapsulated $\mathrm{TiO}_{2}$ nanoparticles $(1.0 \mathrm{mg} / \mathrm{mL})$ in extended GFC-FD analysis, using $\lambda_{\mathrm{ex}, \max }=350 \mathrm{~nm}$ and $\lambda_{\mathrm{em}, \max }=395 \mathrm{~nm}$ for FD.

The flow rate of $1.0 \mathrm{~mL} / \mathrm{min}$ was deemed optimal for all subsequent extended GFC-FD analyses of $\mathrm{TiO}_{2}$ (and other metal oxide) nanoparticles. Encapsulation within lecithin liposomes improved their stability when travelling through the entire length of the gel filtration matrix in the column. Lecithin liposomes apparently carried the $\mathrm{TiO}_{2}$ nanoparticles through the gel column, as evidenced by a larger peak area, without increasing its original retention time-which indicated a relatively large size corresponding to liposomes. Vemuri and Rhodes had previously explored the use of size exclusion chromatography, as a large-scale process, to separate liposomes from free drug in a liposome preparation [52]. Interestingly, lecithin presented no distinct critical micelle concentration in either alcohol solution or water suspension, as Hara et al. had measured using electric conductivity and fluorescence [53]. Hypothetically, in the present work, $\mathrm{TiO}_{2}$ nanoparticles were first stripped of all adsorbed anions by the methanol inside lecithin liposomes. Methanol had previously been used for desorption of picrate anions from magnetic nanoparticles that were coated with cetyltrimethyl-ammonium bromide [54]. Presumably, lecithin molecules dispersed around the bare non-ionic $\mathrm{TiO}_{2}$ nanoparticles that interacted favorably with the hydrophobic lipid moiety of each lecithin molecule. Under strong ultrasonication, they merged to form nanoliposomes, each containing several $\mathrm{TiO}_{2}$ nanoparticles. Being metastable aggregates of lipids [55], coalescence between lecithin nanoliposomes occurred when they were compressed by ultrasonic homogenization [56]. A calibration curve was constructed for the extended GFC analysis of lecithin-bound $\mathrm{TiO}_{2}$ nanoparticles at a flow rate of $1.0 \mathrm{~mL} / \mathrm{min}$, using $\lambda_{\mathrm{ex}, \max }=350 \mathrm{~nm}$ and $\lambda_{\mathrm{em}, \max }=395 \mathrm{~nm}$ for FD. As shown in Figure 9, initially the GFC-FD peak area increased with increasing uptake of $\mathrm{TiO}_{2}$ nanoparticles by the lecithin liposomes, up to $0.03 \mathrm{mg} / \mathrm{mL}$. However, no significant increase in peak area could be observed from 0.03 to $0.06 \mathrm{mg} / \mathrm{mL}$, apparently indicating no further uptake of $\mathrm{TiO}_{2}$ nanoparticles by the lecithin liposomes. Above $0.06 \mathrm{mg} / \mathrm{mL}$, the peak area continued to increase only moderately to suggest a possible restructuring of the $\mathrm{TiO}_{2}$ nanoparticle-loaded lecithin liposomes. Further research needs to elucidate the mechanism of action behind this irregular shape of the calibration curve.

Optimization of the GFC-FD method was carried out by adding different amounts of lecithin liposomes into either distilled deionized water or $\mathrm{TiO}_{2}$ nanoparticles $(1.0 \mathrm{mg} / \mathrm{mL})$. The peak area at $4.15 \mathrm{~min}$ for lecithin liposomes exhibited a linear correlation with the amount of lecithin liposomes as shown in Figure 10. However, a significantly steeper slope was obtained for $\mathrm{TiO}_{2}$ nanoparticles (than that for water). Apparently, the more lecithin liposomes were added, the lower the concentration of $\mathrm{TiO}_{2}$ nanoparticles that would be encapsulated within each and every liposome. Thus, the excitation of $\mathrm{TiO}_{2}$ fluorescence became more efficient and the emission of $\mathrm{TiO}_{2}$ fluorescence became less self-quenched. This strongly suggested that more lecithin liposomes can be used to obtain a larger peak area for any given concentration of $\mathrm{TiO}_{2}$ nanoparticles after subtraction of the lecithin liposomes blank, thereby improving the analytical sensitivity of this extended GFC method. 


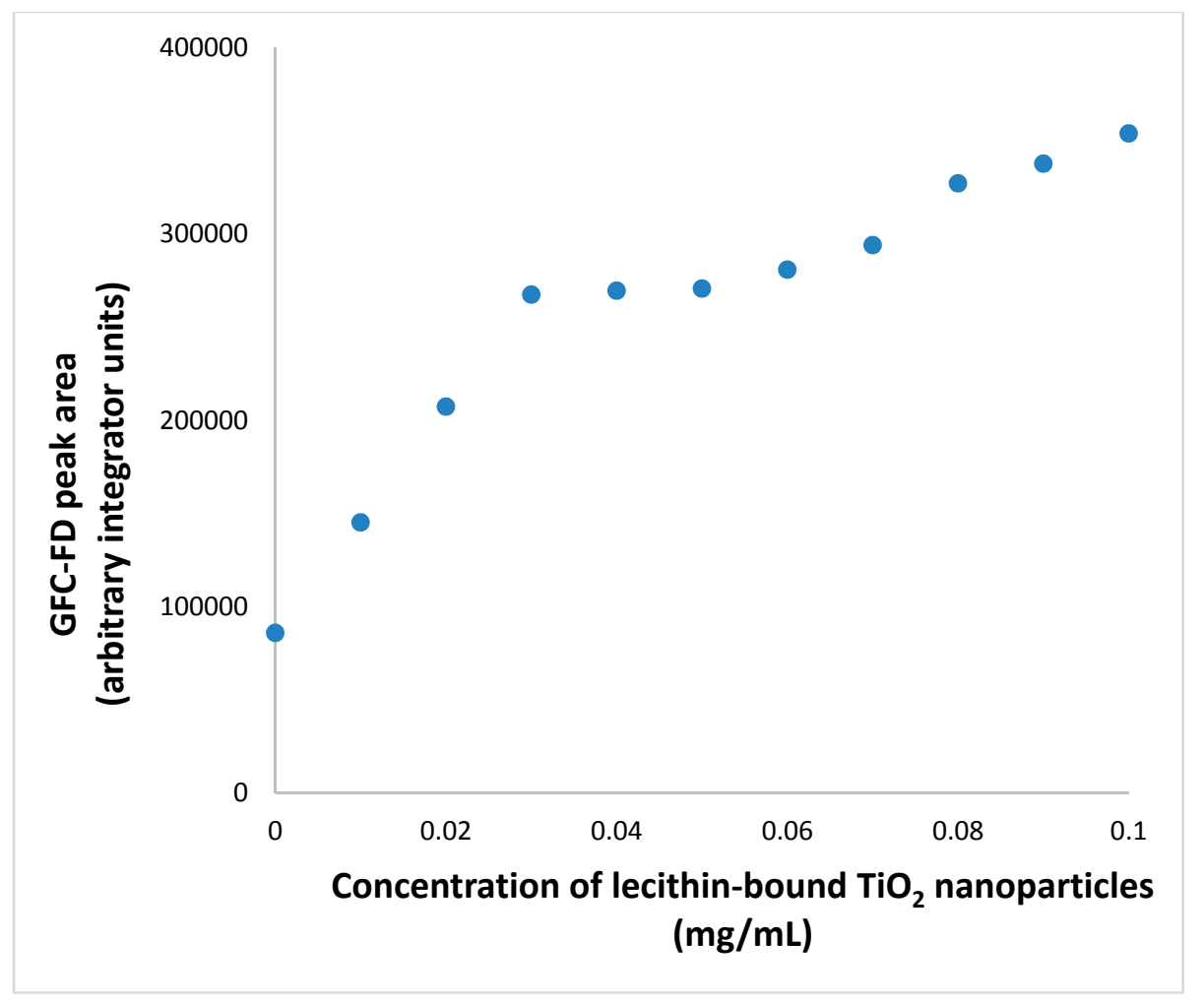

Figure 9. Standard calibration curve for extended GFC analysis of lecithin liposome-encapsulated $\mathrm{TiO}_{2}$ nanoparticles at a flow rate of $1 \mathrm{~mL} / \mathrm{min}$, using $\lambda_{\mathrm{ex}, \max }=350 \mathrm{~nm}$ and $\lambda_{\mathrm{em}, \max }=395 \mathrm{~nm}$ for FD.

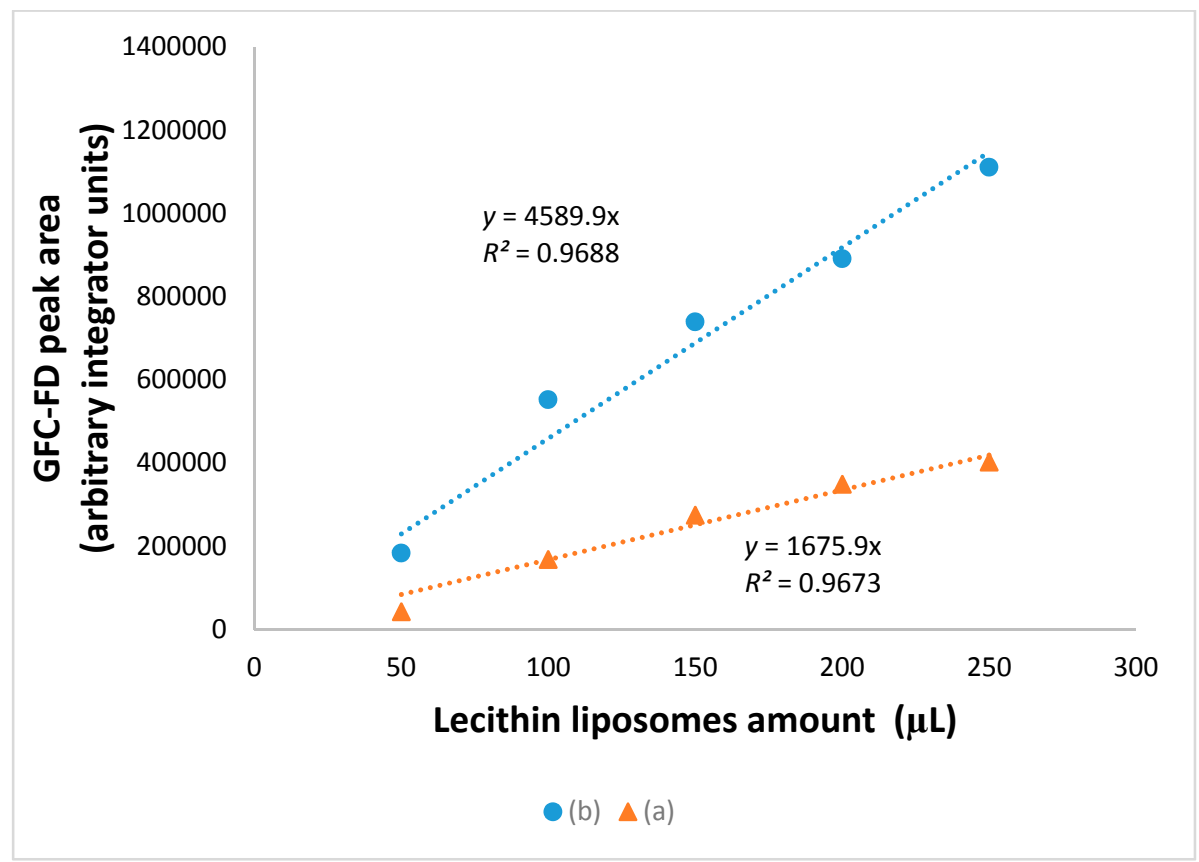

Figure 10. Optimization of lecithin liposomes amount added to (a) distilled deionized water; and (b) $\mathrm{TiO}_{2}$ nanoparticles $(1.0 \mathrm{mg} / \mathrm{mL})$, in extended GFC analysis using $\lambda_{\mathrm{ex}, \max }=350 \mathrm{~nm}$ and $\lambda_{\mathrm{em}, \max }=395 \mathrm{~nm}$ for FD. 


\subsection{Extended GFC-FD Analysis of Lecithin Liposome-Encapsulated ZnO Nanoparticles}

In order to demonstrate the potential application of lecithin liposomes for encapsulating metal oxide nanoparticles other than just $\mathrm{TiO}_{2}$ in water treatment, extended GFC-FD analysis was next performed on lecithin liposome-encapsulated $\mathrm{ZnO}$ nanoparticles, $\mathrm{ZnO}$ nanoparticles, and lecithin liposomes. Just like $\mathrm{TiO}_{2}$, encapsulation of $\mathrm{ZnO}$ nanoparticles within lecithin liposomes allowed them to go through the column together to appear as a combination peak at a retention time of $4.34 \mathrm{~min}$ in Figure 11a. It was next evidenced that $\mathrm{ZnO}$ nanoparticles were strongly retained on the long column until its peak appeared at $11.47 \mathrm{~min}$ in Figure 11b. The chromatogram in Figure 11c shows a peak at 4.15 min with an area linearly proportional to the concentration of lecithin liposomes $\left(R^{2}=0.98\right.$, data not shown). In hindsight, for the sake of contrasting, $\mathrm{TiO}_{2}$ nanoparticles had not shown any peak and lecithin liposome-encapsulated $\mathrm{TiO}_{2}$ nanoparticles had exhibited a retention time of $4.42 \mathrm{~min}$.

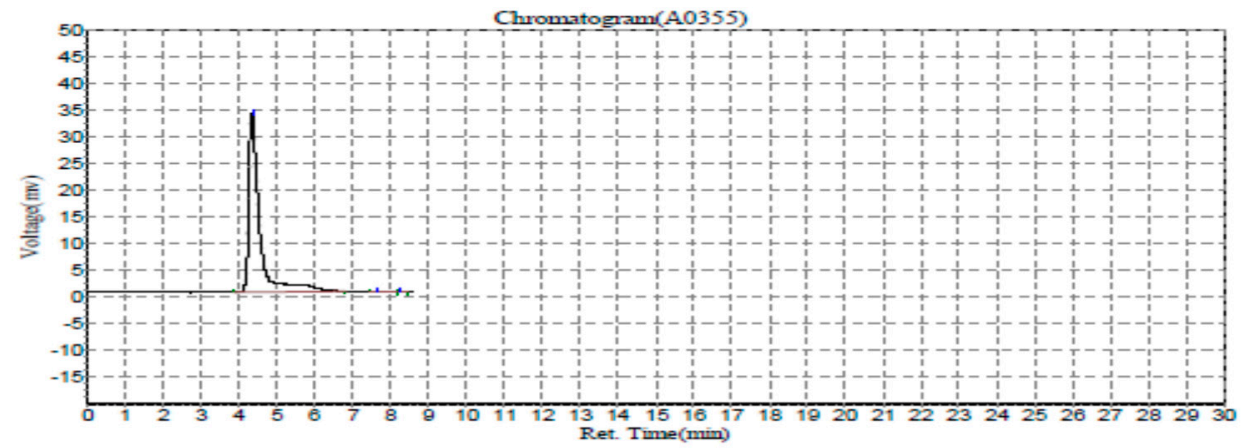

(a)

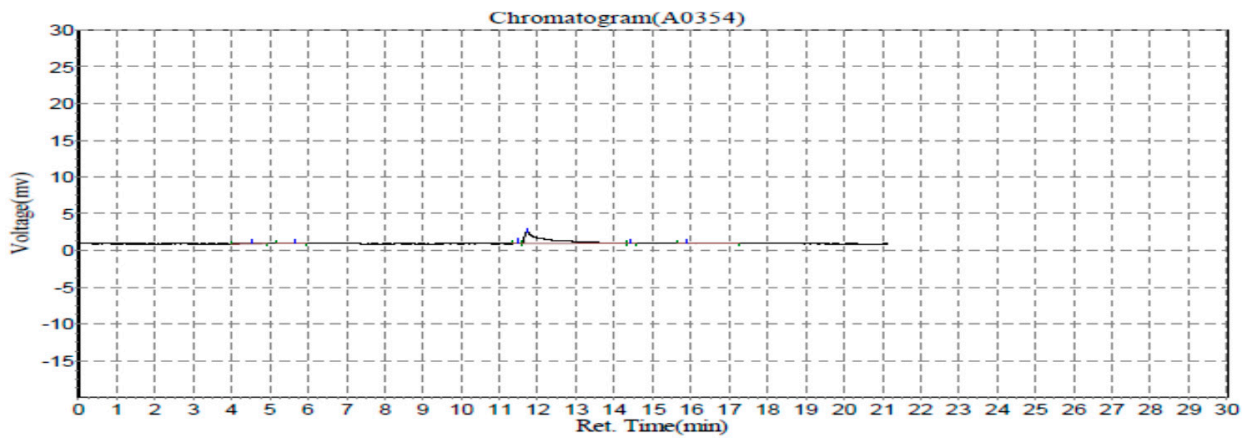

(b)

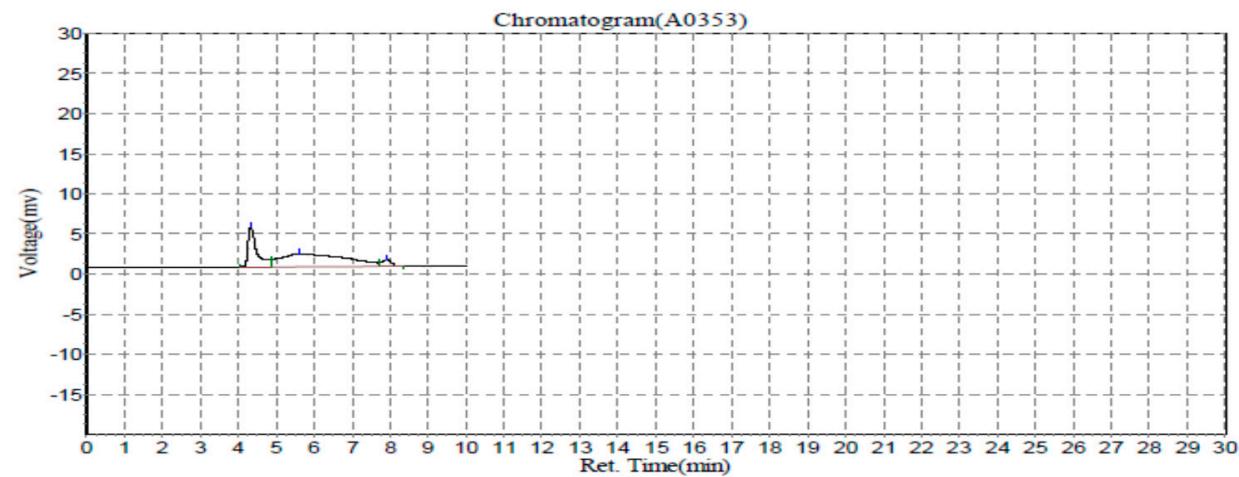

(c)

Figure 11. Extended GFC analysis: (a) lecithin liposome-encapsulated $\mathrm{ZnO}$ nanoparticles $(1.0 \mathrm{mg} / \mathrm{mL})$; (b) $\mathrm{ZnO}$ nanoparticles $(1.0 \mathrm{mg} / \mathrm{mL})$; and (c) lecithin liposomes, using $\lambda_{\mathrm{ex}}=350 \mathrm{~nm}$ and $\lambda_{\mathrm{em}}=395 \mathrm{~nm}$ for FD. 
The peak area of $1.0 \mathrm{mg} / \mathrm{mL}$ lecithin liposome-encapsulated $\mathrm{ZnO}$ nanoparticles was significantly stronger than that of lecithin liposomes alone. A standard calibration curve has been constructed in Figure 12 for the extended GFC analysis at a flow rate of $1.0 \mathrm{~mL} / \mathrm{min}$, using $\lambda_{\mathrm{ex}}=350 \mathrm{~nm}$ and $\lambda_{\mathrm{em}}=395 \mathrm{~nm}$ for FD. Binding of lecithin liposomes with $\mathrm{ZnO}$ nanoparticles is confirmed by the larger peak areas for increasing concentrations from $0.01 \mathrm{mg} / \mathrm{mL}$ to $0.10 \mathrm{mg} / \mathrm{mL}$. For lecithin liposome-encapsulated $\mathrm{ZnO}$ nanoparticles, a detection limit of $0.05 \mathrm{mg} / \mathrm{mL}$ is attained by this GFC-FD method.

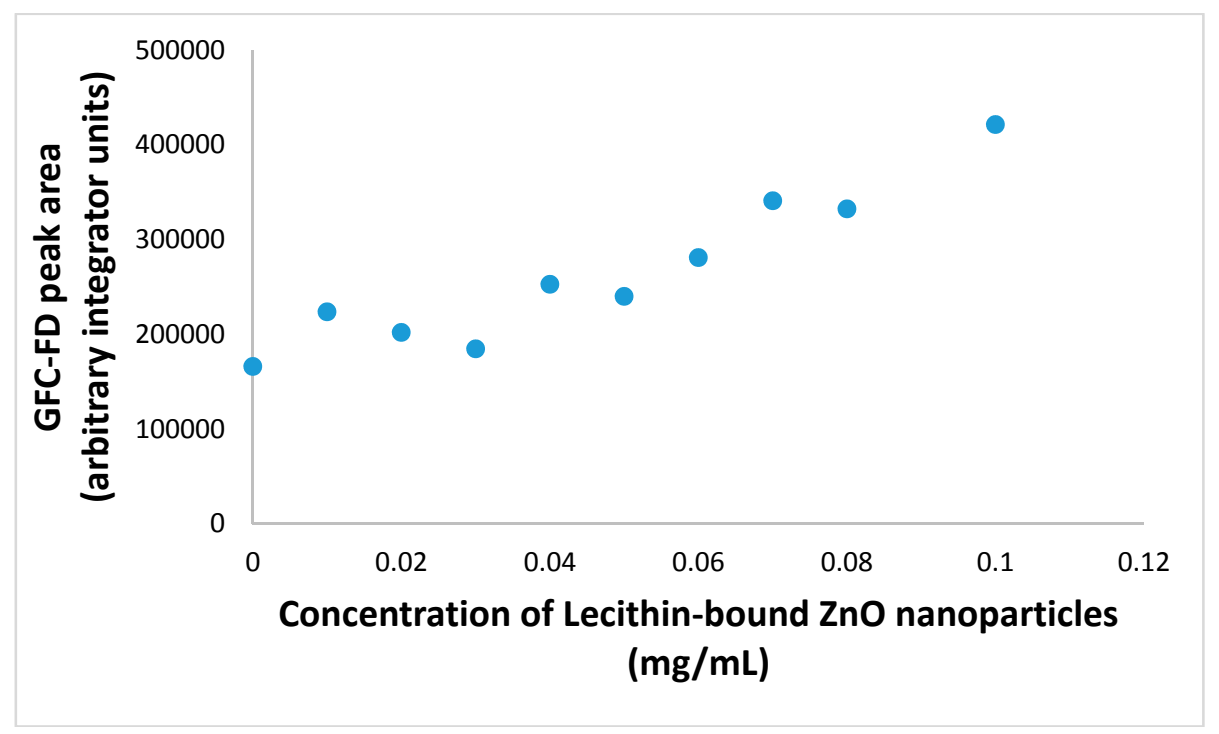

Figure 12. Standard calibration curve for extended GFC analysis of lecithin liposome-bound $\mathrm{ZnO}$ nanoparticles at a flow rate of $1 \mathrm{~mL} / \mathrm{min}$, using $\lambda_{\mathrm{ex}}=350 \mathrm{~nm}$ and $\lambda_{\mathrm{em}}=395 \mathrm{~nm}$ for FD.

\subsection{Extended GFC-FD Analysis of Lecithin Liposome-Encapsulated Graphene Quantum Dots}

It is important to develop a cost effective technology for the removal of $\mathrm{TiO}_{2}$ nanoparticles ranging from industrial wastewater to contaminated drinking water treatment. A limiting factor in drinking water treatment is the ability to collect all the waterborne nanoparticles for removal. Industrial filtration technologies are currently used on a very large scale but they are often plagued by structural variation and surface fouling of membrane filters [57-59]. The results discussed so far show the possibility of using lecithin liposomes for simple water treatment. One monitoring requirement is that the nanoparticle-loaded lecithin liposomes must subsequently be removed from the treated water before it is released to local waterways. Fluorescent GQDs have attracted tremendous attention for a wide range of sensing applications because of their good water dispersibility, high photostability, excellent biocompatibility, and low toxicity [60-62]. They can potentially serve as a sensor probe for monitoring the complete removal of nanoparticle-loaded liposomes from the treated water. Extended GFC analysis of a small aliquot of GQDs that had previously been synthesized and characterized in our lab [19] produced a sharp FD peak at $21.2 \mathrm{~min}$ in Figure 13a, as expected for their small size of 5-6 nm. Extended GFC analysis of GQDs in mixture with lecithin liposome-encapsulated $\mathrm{TiO}_{2}$ nanoparticles showed a significant reduction in the GQDs peak area at $20.8 \mathrm{~min}$ and the appearance of a small peak at $9.4 \mathrm{~min}$ in Figure 13b. This new peak could be attributed to the encapsulation of GQDs by lecithin liposomes (loaded with $\mathrm{TiO}_{2}$ nanoparticles). This result is consistent with a previous work by Chen et al. on the encapsulation of quantum dots in liposomes and the separation of nanoparticle-loaded liposomes from unencapsulated nanoparticles by size exclusion chromatography using a Sepharose gel [63]. They used fluorescence correlation spectroscopy to determine that each liposome encapsulated an average of three quantum dots. Hence, both studies have indicated GQDs can potentially serve the purpose of 
monitoring the nanoparticle-loaded liposomes to track their complete removal from treated water by ultrafiltration using the membrane separation technology $[19,64,65]$.

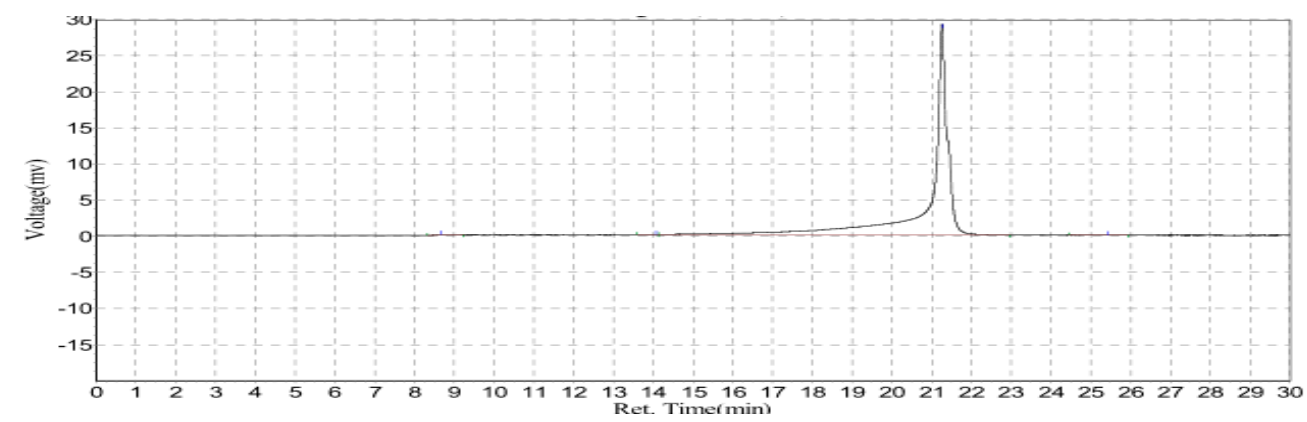

(a)

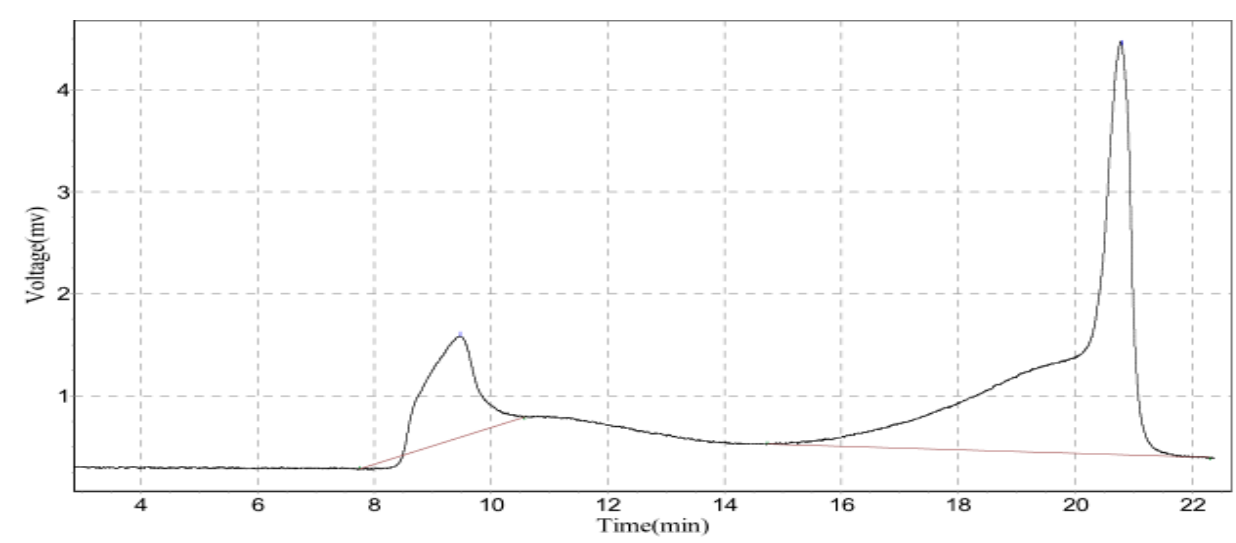

(b)

Figure 13. Extended GFC analysis: (a) GQDs; and (b) GQDs with lecithin liposome-encapsulated $\mathrm{TiO}_{2}$ nanoparticles $(1.0 \mathrm{mg} / \mathrm{mL})$, using $\lambda_{\mathrm{ex}, \max }=350 \mathrm{~nm}$ and $\lambda_{\mathrm{em}, \max }=395 \mathrm{~nm}$ for FD.

\section{Conclusions}

Coating with polydopamine and encapsulation within lecithin liposomes prevent $\mathrm{TiO}_{2}$ and $\mathrm{ZnO}$ nanoparticles from aggregation during extended chromatographic separation through the gel filtration matrix, even in a long column. To the best of our knowledge, this is the first report on the gel filtration chromatographic analysis of lecithin liposomes that demonstrates their potential application for cleaning up two different types of metal oxide nanoparticles in water treatment, at a high efficiency but with a low cost. The colloidal stability of $\mathrm{TiO}_{2}-\mathrm{PDA}$ nanoparticles is important but not crucial for this new method because every sample is homogenized ultrasonically both during encapsulation by lecithin liposomes and before each GFC-FD analysis. In water treatment, unstable nanoparticles form aggregates, undergo sedimentation, and thus do not need liposome encapsulation to clean them up. Considering the importance of industrial wastewater and drinking water treatment technologies, liposomes can be completely removed by membrane ultrafiltration but metal oxide nanoparticles cannot. Further research will need to test whether this method is applicable to environmental matrices with a complex composition. Encapsulation of graphene quantum dots by liposomes will potentially allow monitoring of the nanoparticle-loaded liposomes during their subsequent removal from the treated water before it is released to local waterways or delivered to homes for drinking.

Acknowledgments: Financial support from NSERC Canada (grant number 315574) is gratefully acknowledged. 
Author Contributions: Edward P. C. Lai conceived and designed the experiments; Xuhao Zhao performed the experiments; Xuhao Zhao and Edward P. C. Lai analyzed the data; Edward P. C. Lai and Xuhao Zhao wrote the paper.

Conflicts of Interest: The authors declare no conflict of interest. The funding sponsor had no role in the design of the study; in the collection, analysis, or interpretation of data; in the writing of the manuscript, and in the decision to publish the results.

\section{List of Symbols and Abbreviations}

$\begin{array}{ll}\mathrm{CeO}_{2} & \text { ceria } \\ \mathrm{FD} & \text { fluorescence detection } \\ \mathrm{GFC} & \text { gel filtration chromatography } \\ \lambda_{\text {em,max }} & \text { maximum emission wavelength } \\ \lambda_{\text {ex,max }} & \text { maximum excitation wavelength } \\ \mathrm{PDA} & \text { polydopamine } \\ \mathrm{TiO}_{2} & \text { titania } \\ \mathrm{ZnO} & \text { zinc oxide }\end{array}$

\section{References}

1. Regulatory Cooperation Council. Nanotechnology Initiative. Final Report. Work Element 2, Priority Setting: Development of a Joint Nanomaterials Classification Scheme. Regulatory Cooperation Council. Available online: http:/ / nanoportal.gc.ca/666215CB-929F-4F75-B78C-4D9DD0F1093B/FINAL\%20DRAFT\%20RCC\% 20Nanotechnology\%20Initiative\%20Work\%20Element\%202.pdf (accessed on 4 February 2018).

2. Long, T.C.; Saleh, N.; Tilton, R.D.; Lowry, G.V.; Veronesi, B. Titanium dioxide (P25) produces reactive oxygen species in immortalized brain microglia (BV2): Implications for nanoparticle neurotoxicity. Environ. Sci. Technol. 2006, 40, 4346-4352. [CrossRef] [PubMed]

3. Trouiller, B.; Reliene, R.; Westbrook, A.; Solaimani, P.; Schiestl, R.H. Titanium dioxide nanoparticles induce DNA damage and genetic instability in vivo in mice. Cancer Res. 2009, 69, 8784-8789. [CrossRef] [PubMed]

4. Chang, X.; Zhang, Y.; Tang, M.; Wang, B. Health effects of exposure to nano- $\mathrm{TiO}_{2}$ : A meta-analysis of experimental studies. Nanoscale Res. Lett. 2013. [CrossRef] [PubMed]

5. Grande, F.; Tucci, P. Titanium dioxide nanoparticles: A risk for human health? Mini Rev. Med. Chem. 2016, 16, 762-769. [CrossRef] [PubMed]

6. Disdier, C. Evaluation of the Effects of $\mathrm{TiO}_{2}$ Nanoparticles Exposure on the Adult and Vulnerable Brains-Toxicology and Food Chain. Ph.D. Thesis, University of Paris-Saclay, Paris, France, 2016. Available online: https: / tel.archives-ouvertes.fr/tel-01312182/document (accessed on 4 February 2018).

7. Shah, S.N.A.; Shah, Z.; Hussain, M.; Khan, M. Hazardous effects of titanium dioxide nanoparticles in ecosystem. Bioinorg. Chem. Appl. 2017. [CrossRef] [PubMed]

8. Barndõk, H.; Hermosilla, D.; Han, C.; Dionysiou, D.D.; Negro, C.; Blanco, Á. Degradation of 1,4-dioxane from industrial wastewater by solar photocatalysis using immobilized $\mathrm{NF}^{-\mathrm{TiO}_{2}}$ composite with monodisperse $\mathrm{TiO}_{2}$ nanoparticles. Appl. Catal. B Environ. 2016, 180, 44-52. [CrossRef]

9. Wadhwa, U. Removal of Toxic Metal Ions from Industrial Waste Water by Photo Deposition on $\mathrm{P}-25 \mathrm{TiO}_{2}$ Nanoparticles. Master's Thesis, Thapar Univeristy, Patiala, India, 2016. Available online: http:/ /dspace.thapar. edu:8080/jspui/handle/10266/4302 (accessed on 4 February 2018).

10. Malakootian, M.; Ranandeh Kalankesh, L.; Loloi, M. Investigation of performance of hybrid nanoparticles $\mathrm{TiO}_{2} / \mathrm{SiO}_{2}$ in removing of mercury from industrial waste water. J. Toloo-E-Behdasht 2014, 13, 147-159.

11. Kohri, M.; Yanagimoto, K.; Kawamura, A.; Hamada, K.; Imai, Y.; Watanabe, T.; Ono, T.; Taniguchi, T.; Kishikawa, K. Polydopamine-based 3D colloidal photonic materials: Structural color balls and fibers from melanin-like particles with polydopamine shell layers. ACS Appl. Mater. Interfaces 2017. [CrossRef] [PubMed]

12. Nador, F.; Guisasola, E.; Baeza, A.; Villaecija, M.A.M.; Vallet-Regí, M.; Ruiz-Molina, D. Synthesis of polydopamine-like nanocapsules via removal of a sacrificial mesoporous silica template with water. Chem. Eur. J. 2017, 23, 2753-2758. [CrossRef] [PubMed] 
13. Li, Y.; Jiang, C.; Zhang, D.; Wang, Y.; Ren, X.; Ai, K.; Chen, X.; Lu, L. Targeted polydopamine nanoparticles enable photoacoustic imaging guided chemo-photothermal synergistic therapy of tumor. Acta Biomater. 2017, 47, 124-134. [CrossRef] [PubMed]

14. Ye, W.; Huang, H.; Yang, W.; Wang, X.; Ren, C.; Hu, Q.; Li, Y.; Ren, B. Ultrathin polydopamine film coated gold nanoparticles: A sensitive, uniform, and stable SHINERS substrate for detection of benzotriazole. Analyst 2017, 142, 3459-3467. [CrossRef] [PubMed]

15. Wang, L.; Miao, L.; Yang, H.; Yu, J.; Xie, Y.; Xu, L.; Song, Y. A novel nanoenzyme based on $\mathrm{Fe}_{3} \mathrm{O}_{4}$ nanoparticles@thionine-imprinted polydopamine for electrochemical biosensing. Sens. Actuators B Chem. 2017, 253, 108-114. [CrossRef]

16. Fang, X.; Li, J.; Li, X.; Pan, S.; Zhang, X.; Sun, X.; Shen, J.; Han, W.; Wang, L. Internal pore decoration with polydopamine nanoparticle on polymeric ultrafiltration membrane for enhanced heavy metal removal. Chem. Eng. J. 2017, 314, 38-49. [CrossRef]

17. Rao, Z.; Feng, K.; Tang, B.; Wu, P. Surface Decoration of Amino-Functionalized Metal-Organic Framework/Graphene Oxide Composite onto Polydopamine-Coated Membrane Substrate for Highly Efficient Heavy Metal Removal. ACS Appl. Mater. Interfaces 2017, 9, 2594-2605. [CrossRef] [PubMed]

18. Yan, J.; Yang, L.; Lu, X.; Lee, P.S. Method of Preparing Hollow Metal or Metal Oxide Nano- or Micro-Spheres. U.S. Patents 9,555,557 B2, 31 January 2017.

19. Wang, K.; Lai, E.P.C. Fluorescence quenching of graphene quantum dots by titania nanoparticles in water analysis after coating with polydopamine. J. Mol. Nanotechnol. Nanomed. 2017, 1, 106-114.

20. Li, X.; John, V.T.; He, G.; Zhan, J.; Tan, G.; McPherson, G.; Bose, A.; Sarkar, J. Shear induced formation of patterned porous titania with applications to photocatalysis. Langmuir 2009, 25, 7586-7593. [CrossRef] [PubMed]

21. Shchipunov, Y.; Krekoten, A. Crystalline titania nanoparticles synthesized in nonpolar $\mathrm{L} \alpha$ lecithin liquid-crystalline media in one stage at ambient conditions. Colloids Surf. B Biointerfaces 2011, 87, 203-208. [CrossRef] [PubMed]

22. Taladrid, D.; Marín, D.; Alemán, A.; Álvarez-Acero, I.; Montero, P.; Gómez-Guillén, M.C. Effect of Chemical Composition and Sonication Procedure on Properties of Food-Grade Soy Lecithin Liposomes with Added Glycerol. Food Res. Int. 2017, 100, 541-550. [CrossRef] [PubMed]

23. Zabodalova, L.A.; Chernjavskij, V.A.; Ishchenko, T.N.; Skvortcova, N.N. Production of liposomes from soybean lecithin. Sci. J. NRU ITMO 2011, 2, UDC 665.372+544.77.

24. Mohan, A.; Rajendran, S.R.C.K.; Thibodeau, J.; Bazinet, L.; Udenigwe, C.C. Liposome Encapsulation of Anionic and Cationic Whey Peptides: Influence of Peptide Net Charge on Nanoliposome Formation and Properties. LWT Food Sci. Technol. 2018, 87, 40-46. [CrossRef]

25. Jin, H.H.; Lu, Q.; Jiang, J.G. Curcumin liposomes prepared with milk fat globule membrane phospholipids and soybean lecithin. J. Dairy Sci. 2016, 99, 1780-1790. [CrossRef] [PubMed]

26. Panahi, Y.; Farshbaf, M.; Mohammadhosseini, M.; Mirahadi, M.; Khalilov, R.; Saghfi, S.; Akbarzadeh, A. Recent advances on liposomal nanoparticles: Synthesis, characterization and biomedical applications. Artif. Cells Nanomed. Biotechnol. 2017, 45, 788-799. [CrossRef] [PubMed]

27. Guner, S.; Oztop, M.H. Food grade liposome systems: Effect of solvent, homogenization types and storage conditions on oxidative and physical stability. Colloids Surf. A Physicochem. Eng. Asp. 2017, 513, 468-478. [CrossRef]

28. Sahu, A.K.; Jain, V. Screening of process variables using Plackett-Burman design in the fabrication of gedunin-loaded liposomes. Artif. Cells Nanomed. Biotechnol. 2017, 45, 1011-1022. [CrossRef] [PubMed]

29. Nguyen, T.L.; Nguyen, T.H.; Nguyen, D.H. Development and in vitro evaluation of liposomes using soy lecithin to encapsulate paclitaxel. Int. J. Biomater. 2017, 2017. [CrossRef] [PubMed]

30. Nkanga, C.I.; Krause, R.W.; Noundou, X.S.; Walker, R.B. Preparation and characterization of isoniazid-loaded crude soybean lecithin liposomes. Int. J. Pharm. 2017, 526, 466-473. [CrossRef] [PubMed]

31. Naeem, S.; Kiew, L.V.; Chung, L.Y.; Fui, K.S.; Misran, M.B. A comparative approach for the preparation and physicochemical characterization of lecithin liposomes using chloroform and non-halogenated solvents. J. Surfactants Deterg. 2015, 18, 579-587. [CrossRef]

32. Roberts, S.A.; Parikh, N.; Blower, R.J.; Agrawal, N. SPIN: Rapid synthesis, purification, and concentration of small drug-loaded liposomes. J. Liposome Res. 2017. [CrossRef] [PubMed] 
33. Nayak, D.; Boxi, A.; Ashe, S.; Thathapudi, N.C.; Nayak, B. Stavudine loaded gelatin liposomes for HIV therapy: Preparation, characterization and in vitro cytotoxic evaluation. Mater. Sci. Eng. C 2017, 73, 406-416. [CrossRef] [PubMed]

34. Cheraghi, M.; Negahdari, C.B.; Daraee, H.; Eatemadi, A. Heart targeted nanoliposomal/nanoparticles drug delivery: An updated review. Biomed. Pharmacother. 2017, 86, 316-323. [CrossRef] [PubMed]

35. Barenholz, A.L.; Barenholz, Y.; Bercovier, H. Nano-liposomes of crude soy lecithin are effective for cleaning fuel-contaminated sands and soils. Expert Opin. Environ. Biol. 2016, 5. [CrossRef]

36. Simões, M.G.; Alves, P.; Carvalheiro, M.; Simões, P.N. Stability effect of cholesterol-poly(acrylic acid) in a stimuli-responsive polymer-liposome complex obtained from soybean lecithin for controlled drug delivery. Colloids Surf. B Biointerfaces 2017, 152, 103-113. [CrossRef] [PubMed]

37. Hao, J.; Guo, B.; Yu, S.; Zhang, W.; Zhang, D.; Wang, J.; Wang, Y. Encapsulation of the flavonoid quercetin with chitosan-coated nano-liposomes. LWT Food Sci. Technol. 2017, 85A, 37-44. [CrossRef]

38. Zhao, Y.; Zhao, J.; Shan, G.; Yan, D.; Chen, Y.; Liu, Y. SERS-active liposome@Ag/Au nanocomposite for NIR light-driven drug release. Colloids Surf. B Biointerfaces 2017, 154, 150-159. [CrossRef] [PubMed]

39. O'Fagain, C.; Cummins, P.M.; O'Connor, B.F. Protein Chromatography; Methods in Molecular Biology Book Series; Humana Press: New York, NY, USA, 2017; Volume 681, pp. 25-33.

40. Hagel, L. Gel-Filtration Chromatography. Curr. Protoc. Mol. Biol. 2001. [CrossRef]

41. Fedotov, P.S.; Vanifatova, N.G.; Shkinev, V.M.; Spivakov, B.Y. Fractionation and characterization of nano- and micro-particles in liquid media. Anal. Bioanal. Chem. 2011, 400, 1787-1804. [CrossRef] [PubMed]

42. Malvern Instruments Limited. Size Exclusion Chromatography/Gel Permeation Chromatography: An Introduction in 30 Minutes; Malvern Instruments Limited: Malvern, UK, 2015. Available online: https://cdn. technologynetworks.com/TN/Resources/PDF/WP150625IntroToSECGPC.pdf (accessed on 4 February 2018).

43. Preecha, P.; Jettanasen, J. Investigation of functionalized silicon nanoparticles by size exclusion chromatography. Mater. Res. Express 2017, 4, 045007. [CrossRef]

44. Pitkänen, L.; Bustos, A.R.M.; Murphy, K.E.; Winchester, M.R.; Striegel, A.M. Quantitative characterization of gold nanoparticles by size-exclusion and hydrodynamic chromatography, coupled to inductively coupled plasma mass spectrometry and quasi-elastic light scattering. J. Chromatogr. A 2017, 59-67. [CrossRef] [PubMed]

45. French, R.A.; Jacobson, A.R.; Kim, B.; Isley, S.L.; Penn, R.L.; Baveye, P.C. Influence of ionic strength, pH, and cation valence on aggregation kinetics of titanium dioxide nanoparticles. Environ. Sci. Technol. 2009, 43, 1354-1359. [CrossRef] [PubMed]

46. Ikeguchi, Y.; Nakamura, H. Selective enrichment of phospholipids by Titania. Anal. Sci. 2000, 16, 541-543. [CrossRef]

47. Chibowski, E.; Holysz, L.; Terpilowski, K. Influence of ionic surfactants and lecithin on stability of titanium dioxide in aqueous electrolyte solution. Croat. Chem. Acta 2007, 80, 395-403.

48. Byung, G.; Jong, H.; Jin, H.; Kyoung, C. Inorganic-organic nano-hybrid: Preparation of nano-sized $\mathrm{TiO}_{2}$ paste trapped OMC nano-emulsion and its application for cosmetics. J. Soc. Cosmet. Sci. Korea 2004, 30, 181-187.

49. Logeta, G.; Yoo, J.E.; Mazare, A.; Wang, L.; Schmuki, P. Highly controlled coating of biomimetic polydopamine in $\mathrm{TiO}_{2}$ nanotubes. Electrochem. Commun. 2015, 52, 41-44. [CrossRef]

50. Mao, W.X.; Lin, X.J.; Zhang, W.; Chi, Z.X.; Lyu, R.W.; Cao, A.M.; Wan, L.J. Core-shell structured $\mathrm{TiO}_{2} @$ polydopamine for highly active visible-light photocatalysis. Chem. Commun. 2016, 52, 7122-7125. [CrossRef] [PubMed]

51. Krüger, S.; Bürmann, L.; Morlock, G.E. Comparison and characterization of soybean and sunflower lecithins used for chocolate production by high-performance thin-layer chromatography with fluorescence detection and electrospray mass spectrometry. J. Agric. Food Chem. 2015. [CrossRef] [PubMed]

52. Vemuri, S.; Rhodes, C.T. Separation of liposomes by a gel filtration chromatographic technique: A preliminary evaluation. Pharm. Acta Helv. 1994, 69, 107-113. [CrossRef]

53. Hara, I.; Kaneko, H.; Kato, A. The critical micelle concentration of phospholipids-Lecithin and lysolecithin. J. Jpn. Oil Chem. Soc. 1960, 9, 407-409. [CrossRef]

54. Parham, H.; Zargar, B.; Rezazadeh, M. Removal, preconcentration and spectrophotometric determination of picric acid in water samples using modified magnetic iron oxide nanoparticles as an efficient adsorbent. Mater. Sci. Eng. C 2012, 32, 2109-2114. [CrossRef] 
55. Li, L.; Braiteh, F.S.; Kurzrock, R. Liposome-encapsulated curcumin: In vitro and in vivo effects on proliferation, apoptosis, signaling, and angiogenesis. Cancer 2005, 104, 1322-1331. [CrossRef] [PubMed]

56. Taylor, P.; Xu, C.; Fletcher, P.D.I.; Paunov, V.N. A novel technique for preparation of monodisperse giant liposomes. Chem. Commun. 2003, 14, 1732-1733. [CrossRef]

57. Duke, M.; Zhao, D.; Semiat, R. (Eds.) Functional Nanostructured Materials and Membranes for Water Treatment; Wiley \& Sons: Hoboken, NJ, USA, 2013.

58. Saleh, T.A.; Gupta, V.K. (Eds.) Nanomaterial and Polymer Membranes: Synthesis, Characterization, and Applications; Elsevier: Amsterdam, The Netherlands, 2016.

59. Grumezescu, A.M. (Ed.) Water Purification; Academic Press: London, UK, 2017.

60. Zhou, S.; Xu, H.; Gan, W.; Yuan, Q. Graphene quantum dots: Recent progress in preparation and fluorescence sensing applications. RSC Adv. 2016, 6, 110775-110788. [CrossRef]

61. Lai, E.P.C. Carbon, graphene and graphene oxide quantum dots for analytical biochemistry research. Biochem. Anal. Biochem. 2016, 5. [CrossRef]

62. Lai, E.P.C. Graphene quantum dots for bioanalytical sensors and biochemical imaging applications. J. Res. Anal. 2017, 3, 84-90.

63. Chen, C.S.; Yao, J.; Durst, R.A. Liposome encapsulation of fluorescent nanoparticles: Quantum dots and silica nanoparticles. J. Nanopart. Res. 2006, 8, 1033-1038. [CrossRef]

64. Bennett, A. Membrane Technology: Developments in Ultrafiltration Technologies. Filtr. Sep. 2012, 49, $28-33$. [CrossRef]

65. Lohwacharin, J.; Takizawa, S. Effects of nanoparticles on the ultrafiltration of surface water. J. Membr. Sci. 2009, 326, 354-362. [CrossRef]

(C) 2018 by the authors. Licensee MDPI, Basel, Switzerland. This article is an open access article distributed under the terms and conditions of the Creative Commons Attribution (CC BY) license (http:/ / creativecommons.org/licenses/by/4.0/). 